\title{
Career Excellence between Leadership Roles and Achievement Motivation for Employees in the Ministry of Education in the United Arab Emirates
}

\section{Mona Jawad Salman*}

Faculty of Leadership and Management,

43 University Science Islamic Malaysian (USIM)

Malaysia.

Email: mona.allawati@gmail.com

\section{Mohamed Battour}

Faculty of Leadership and Management,

University Science Islamic Malaysian (USIM),

Malaysia and Faculty of commerce Tanta University,

Egypt.

Received September, 2020; Accepted December, 2020

\begin{abstract}
This study aims to analyze the leadership impact on employees' motivation and career excellence in the Ministry of Education in the United Arab Emirates (UAE). The study relies on a questionnaire composed of (5) axes, (10) paragraphs and (55) phrases. The survey was structured based on the following criteria: the model of government leadership in the UAE, the criteria for job excellence adopted in government excellence, the EFQM (The European Foundation for Quality Management) Model, and the achievement motivation for Mwary and McClelland. The sample consists of 283 distinguished employees in the ministry (a rate of 30\% of total distinguished employees) who won three awards: Khalifa Education Award 2007, Hamdan bin Rashid Al Maktoum for Distinguished Academic Performance in 1998, and Sharjah Award for Excellence 1995. Employees were chosen in a random stratified method to ensure a fair and varied representation. The study uses the quantitative and descriptive approaches. Results show that job excellence is moderately affected by the leadership style while it is highly affected by distinguished employees' own motives and practices. In addition, job excellence is moderately affected by competition standards, which is attributed to the need to enhance work conditions and competitive environment in the Ministry of Education. The study concludes with important recommendations to the Ministry of Education, leaders, managers, award departments, and distinguished winners in various categories.
\end{abstract}

Keywords: Excellence; Career Excellence; leadership; Achievements Motivation; Awards; Hamdan Bin Rashid Award; Khalifa Education Award; Sharjah Award; United Arab Emirates.

Type: Research paper

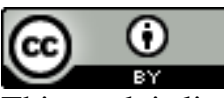

This work is licensed under a Creative Commons Attribution 4.0 International License.

\section{DOI: 10.51325/ijbeg.v3i1.33}

التميّز الوظيفي بين أدوار القيادة ودافعية الإنجاز للموطفين في وزارة التربية والتعليم بدولة الإمارات العربية المتحدة

$$
\begin{aligned}
& \text { الملخص: } \\
& \text { تهدف الدراسة إيجاد أثر أدوار القيادة ودافعية الإنجاز في تحقيق التميّز الوظيفي للعاملين في وزارة التربية والتعليم }
\end{aligned}
$$

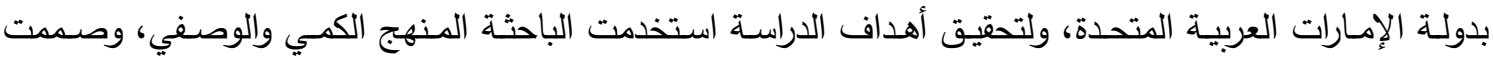

$$
\begin{aligned}
& \text { الاستبانة كأداة للدراسة. تم صياغة الاستبانة في (5) محاور و (10) فقرات و (55) عبارة، مصدرها: أنموذج القيادة } \\
& \text { الحكومية في دولة الإمارات، ومعايير التميز الوظيفي المعتمدة في منظومة التميز الحكومي، والمتوافقة مع معايير }
\end{aligned}
$$

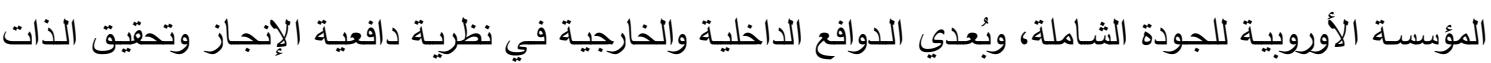


لمواري وماكيلاند، ومعايير قياس أدوار جوائز التميز الوظيفي ومدى ملائكسة معايير التتافس. يتكون مجتمع الدراسة

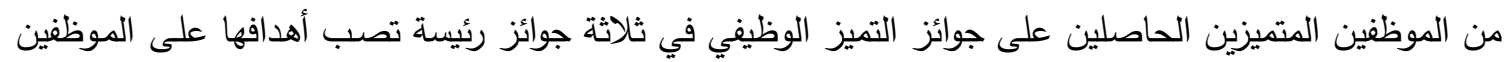

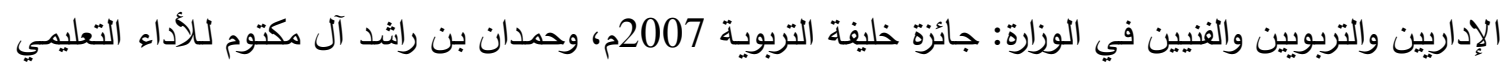
المتميز 1998م، وجائزة الثـارقة للتفوق والتميز التربوي 1995م. وقد بلغ عددهم (944) موظفاً متميزاً، ومثلت العينة (283) موظفاً بنسبة (30\%) من مجتمع الدراسة، تم اختيارهم بطريقة الطبقية العشوائية لضمان تمثيل عادل

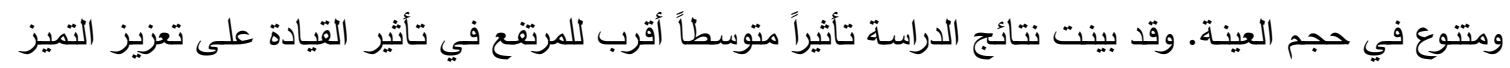

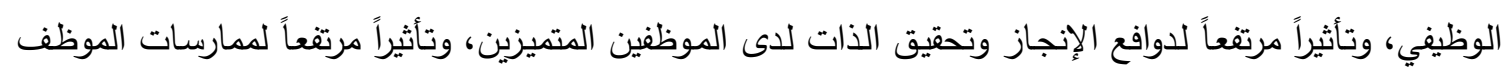

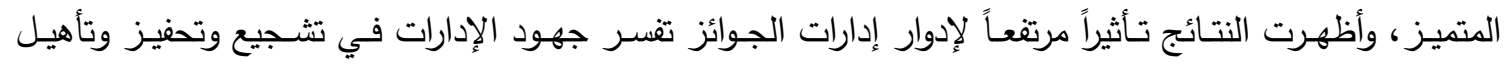
المتميزين، بينما أظهرت تأثيراً متوسطاً لمعايير التتافس يعزي ذلك الحاجة إلى إلى المزيد من الواقعية والملائكة لظروف

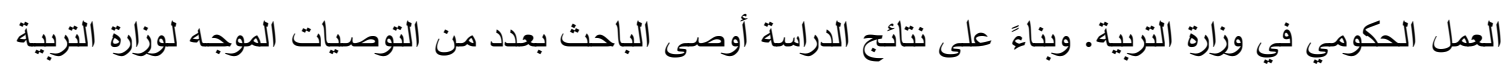

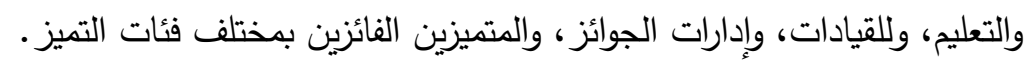

الكلمات المفتاحية: التميز ، التميز الوظيفي، القيادة، دافعية الإنجاز ، الجوائز، جائزة حمدان بن راشد، جائزة خليفة

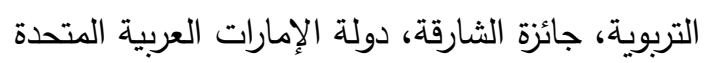

\section{1}

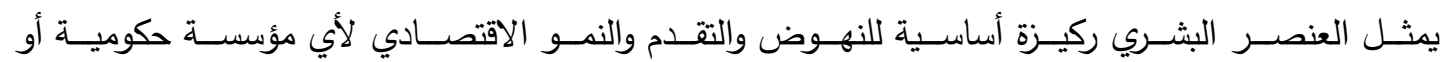

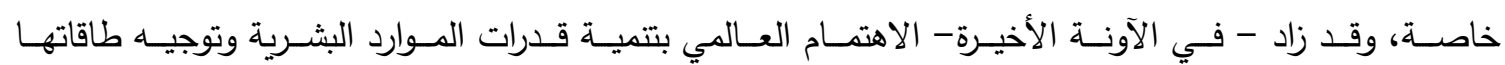

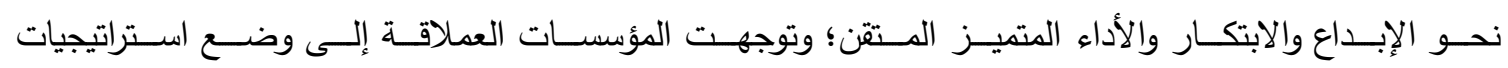

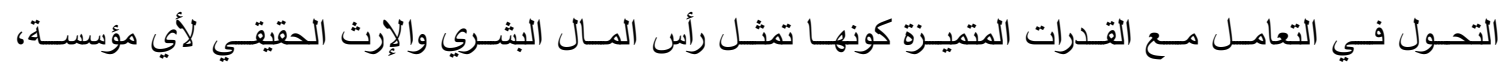

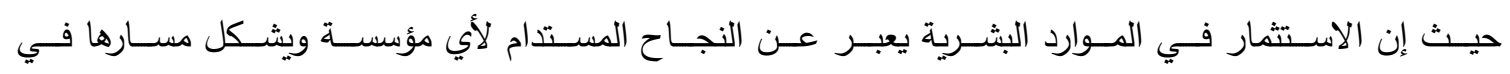

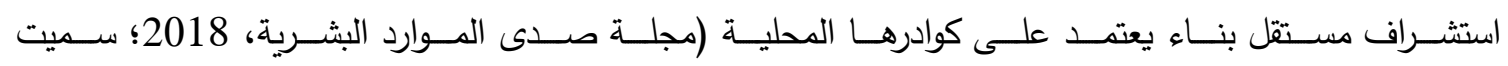

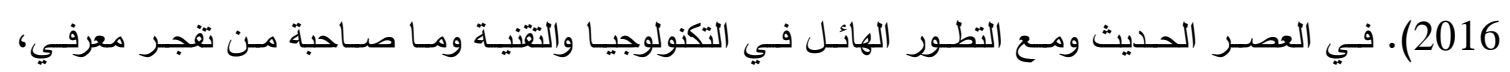

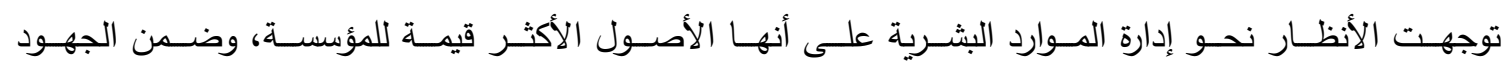

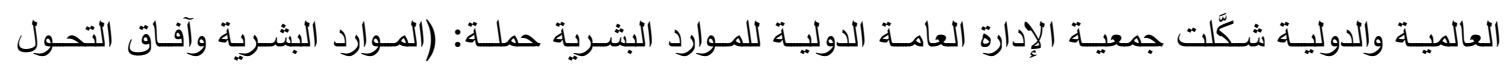

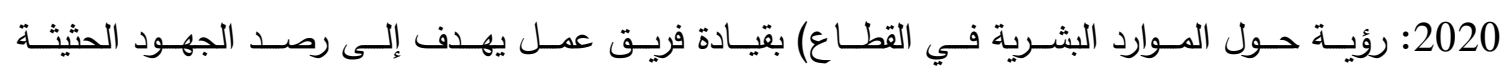

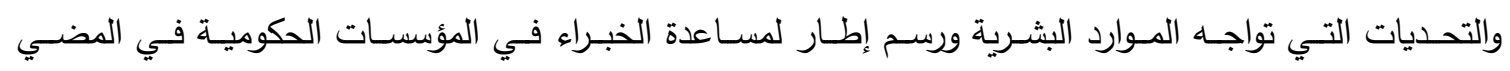

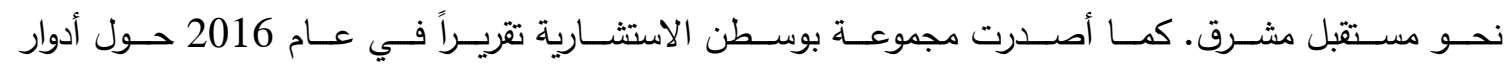

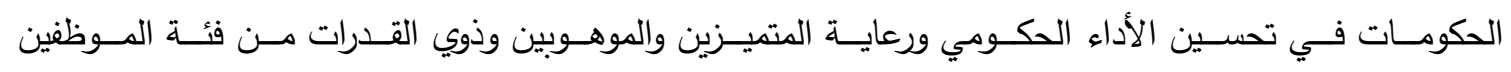

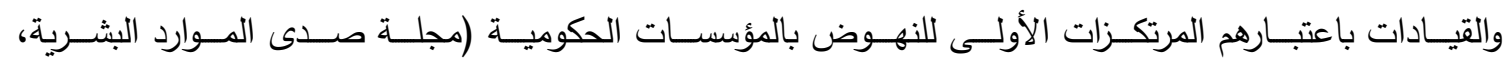

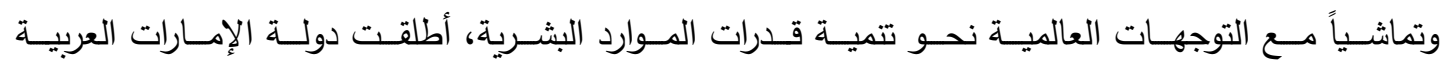

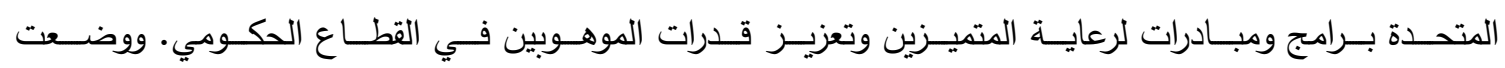

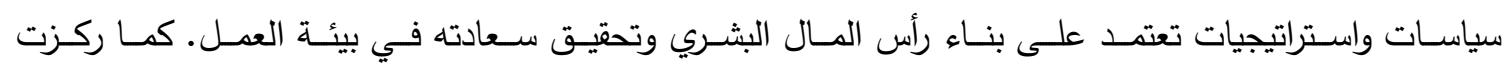

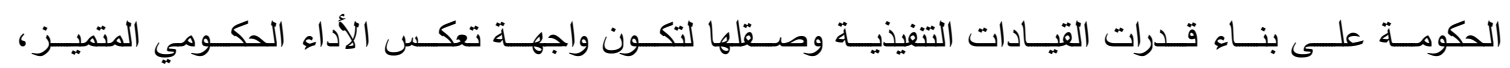


وطـورت فـي 2018 أنموذجـاً للقيـادة الحكوميـة بـثلاث مبـادئ رئيسـة لممارسـات القيـادة: النظـرة المسـتقبلية

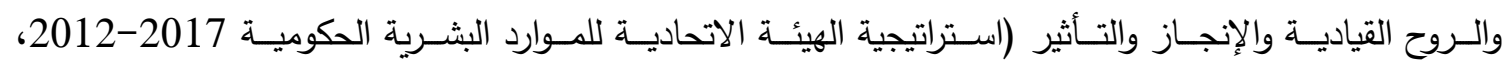

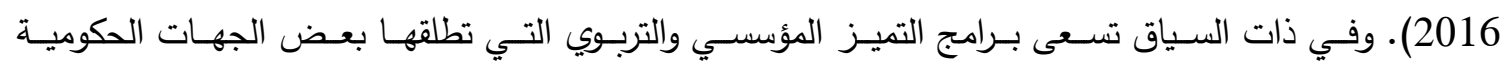

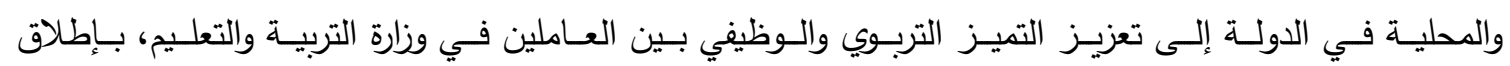

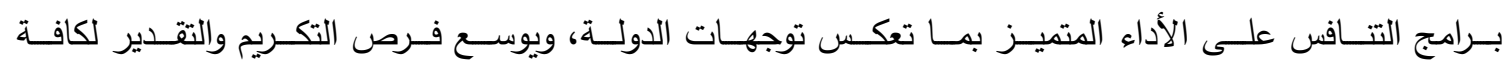

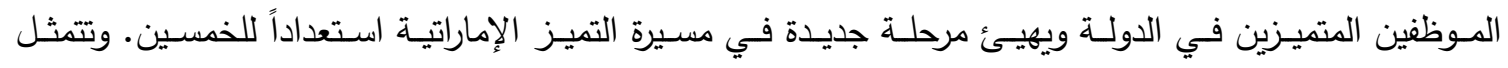

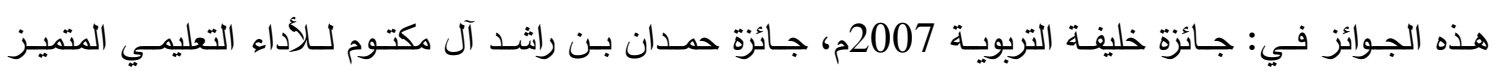
1998م، جائزة الثارقة للتفوق والتميز التربوي 1995م (منظومة التميز الحكومي، 2020).

1.2

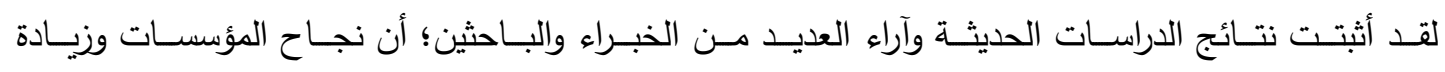

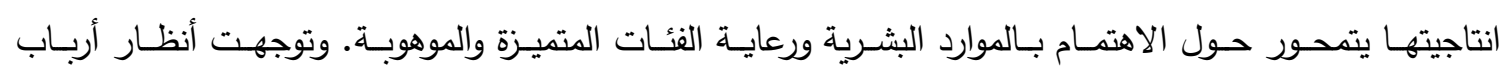

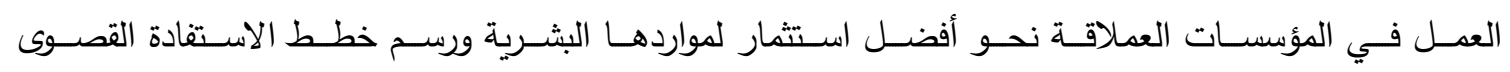

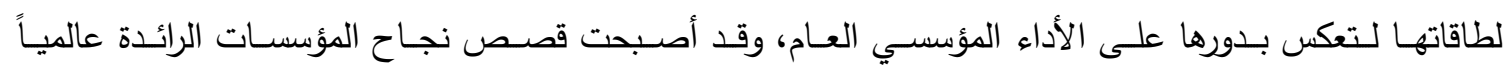

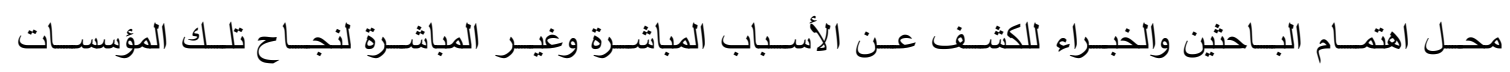

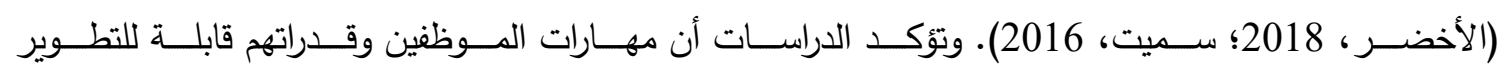

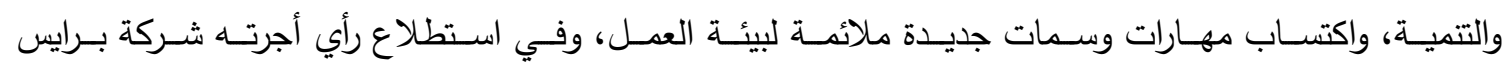

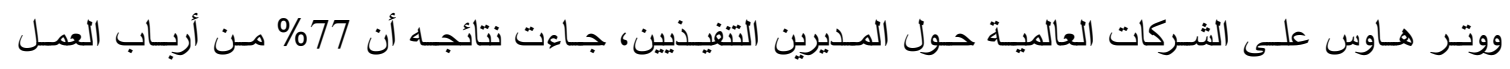

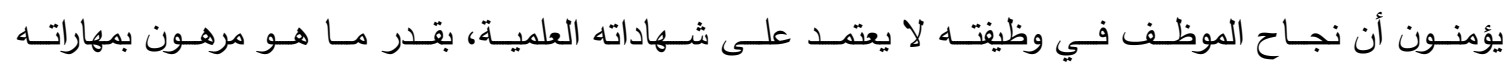

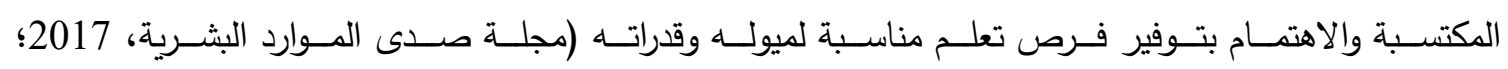
2010، International Youth Foundation, 2016;

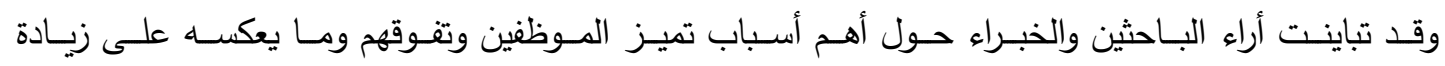

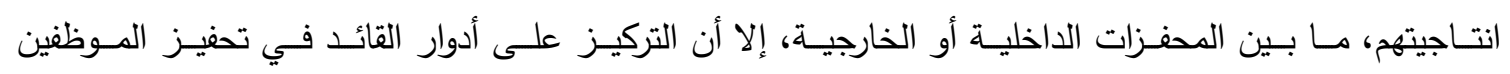

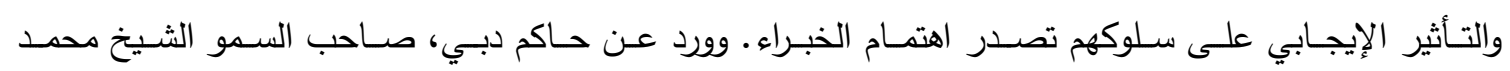

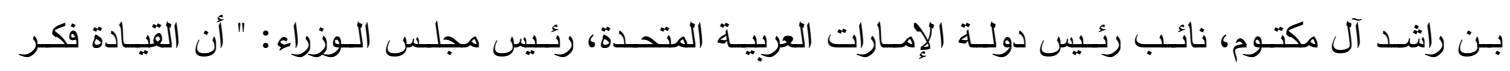

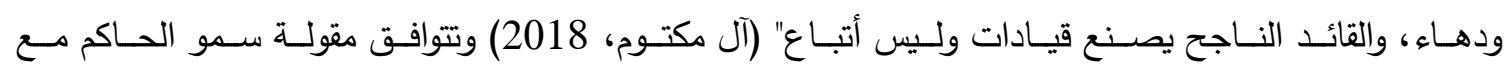

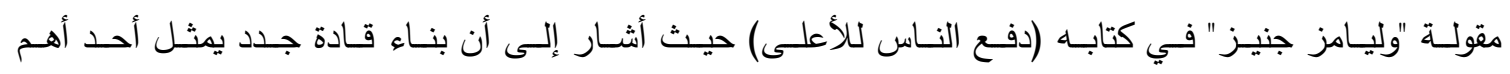

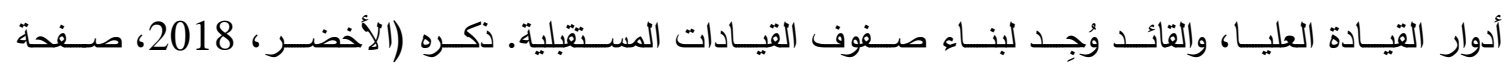

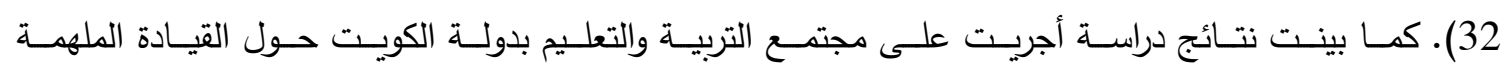

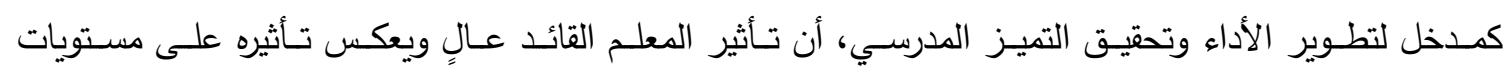

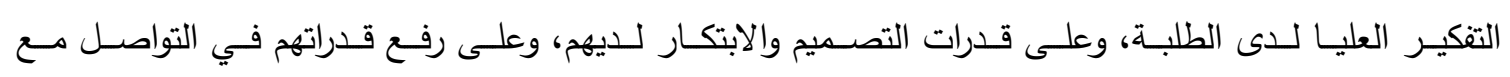

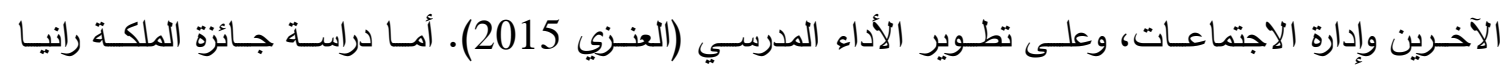

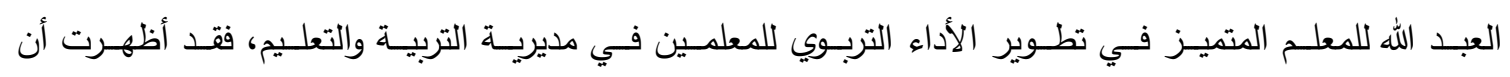

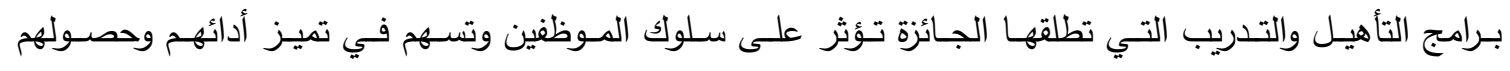

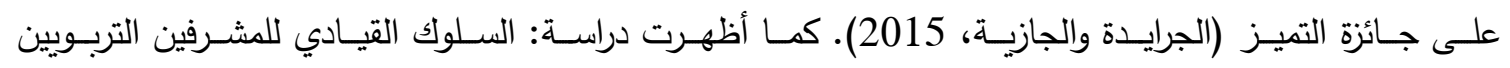


في التعامـل مـع المعلمـين، بمديريـة التربيـة في ولايـة مستغانم فـي الجزائر ، أن المشـرفين التربـويين يمارسـون

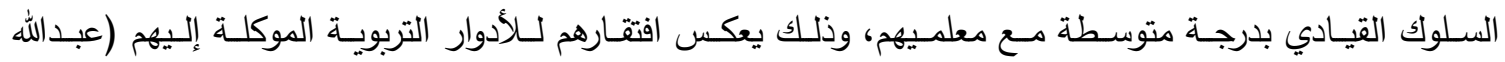

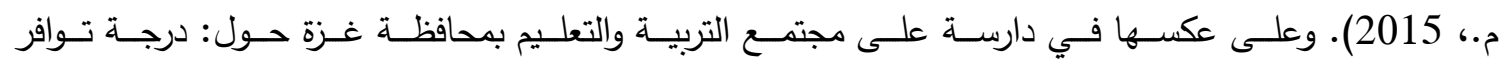

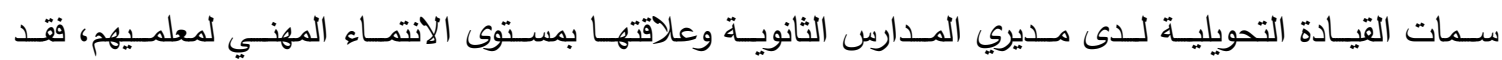

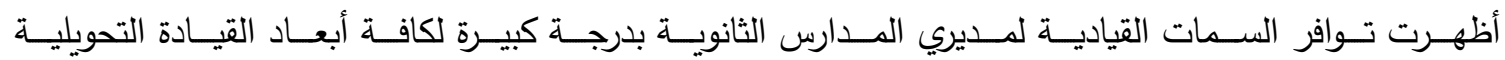

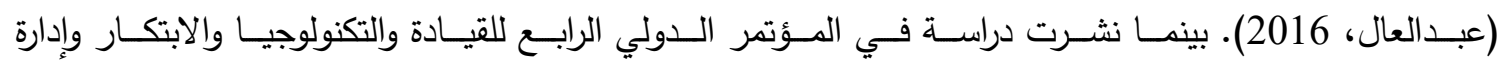

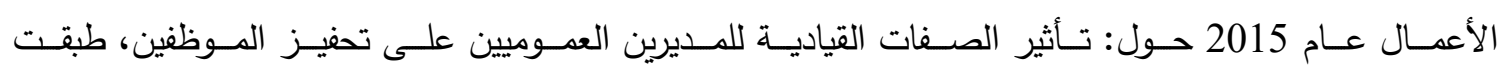
على مجتمـع حكـومي فـي اسـطنبول بمسـتويات وخلفيـات وظيفيـة منوعـة، أظهـرت أن الصـفات الثخصـية

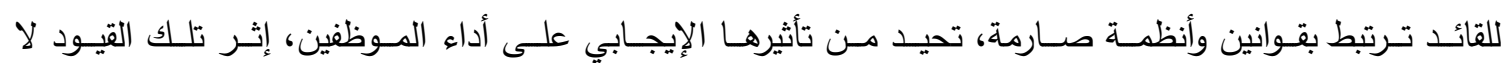
يوجد أثر للقيـادات على المـوظفين (Apak, Gümüs, 2015). وفي دراسـة أثر النمط القيـادي على أداء

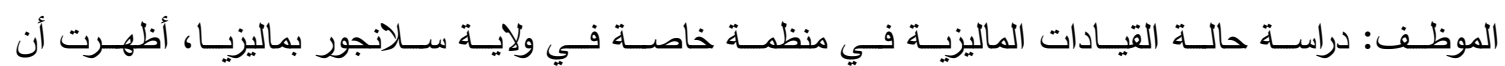

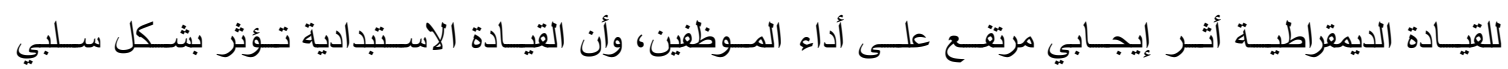
وتخفض نسبة الأداء المهني والانتاجيـة (Basit, Sebastian, \& Hassan, 2017). أمـا دراسـة: دور

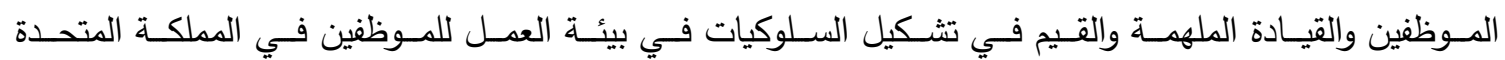

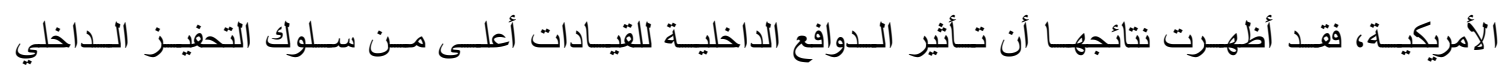

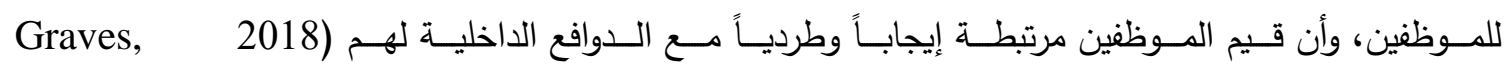
.(Sarkis,

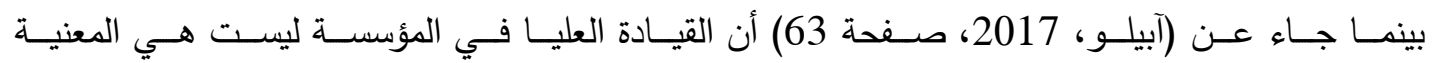

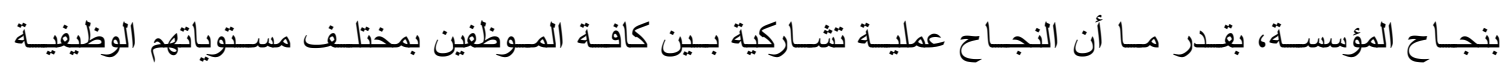

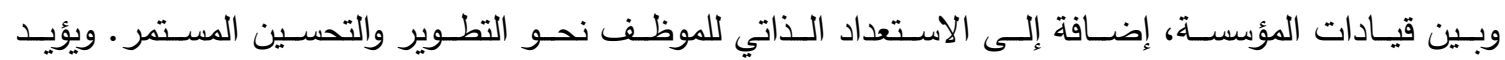

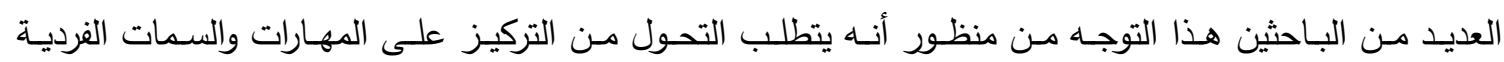

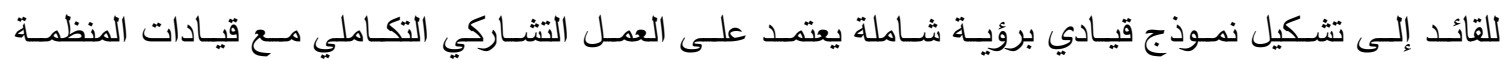
(حسنين، 2019).

في هـذا الصـدد، اهتمـت المؤسسـات الحكوميـة فـي دولـة الإمـارات ببنـاء القـدرات القياديـة، لتتماشـى مـع

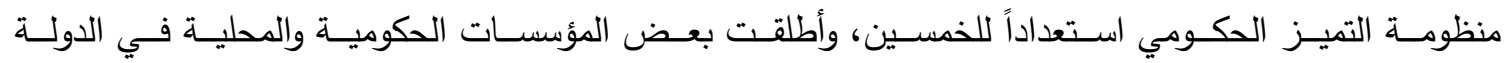

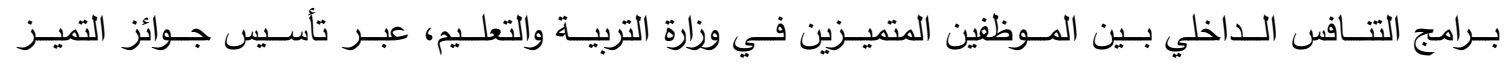

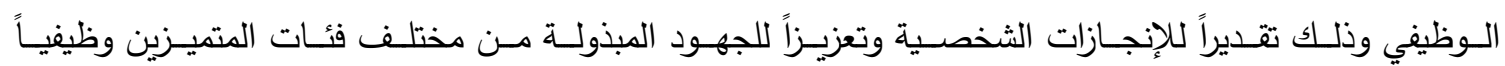

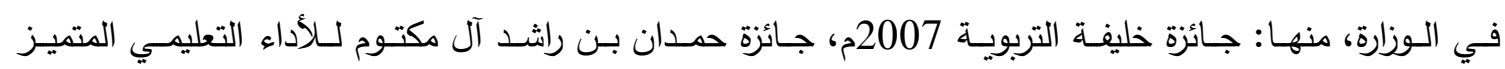

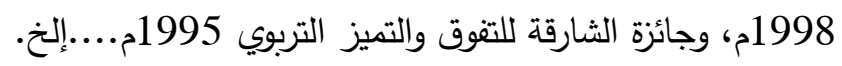

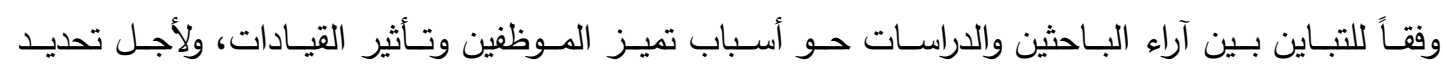

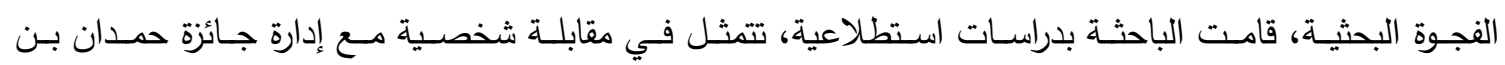

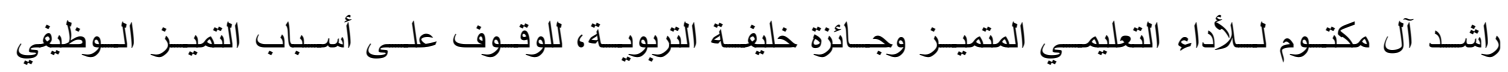

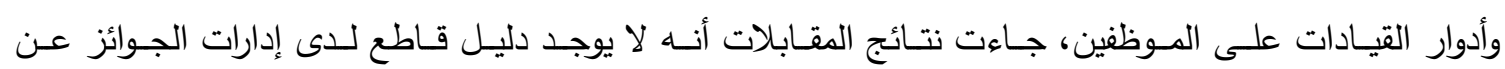




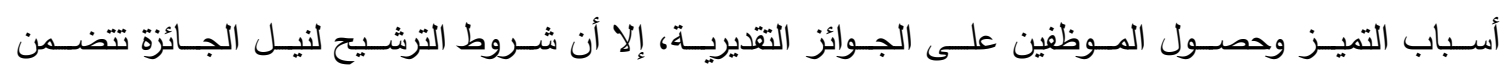

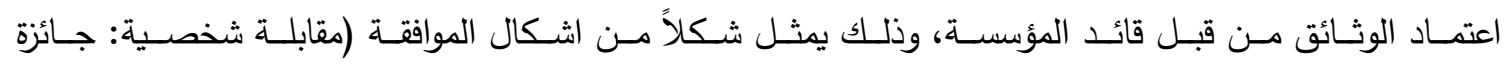

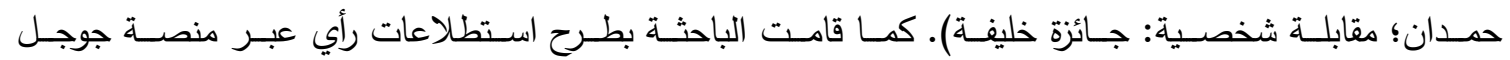

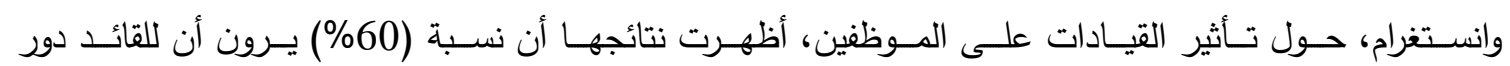

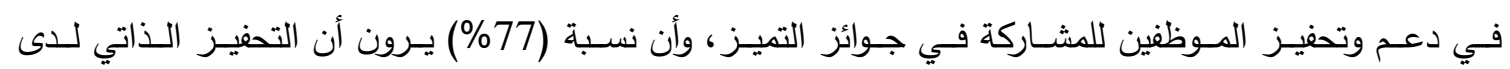
الموظفين أكثر تأثيراً من التحفيز الخارجي، في ضوفي ذلكين يمكن أن تتمحر مشكلة الدراسة حول:

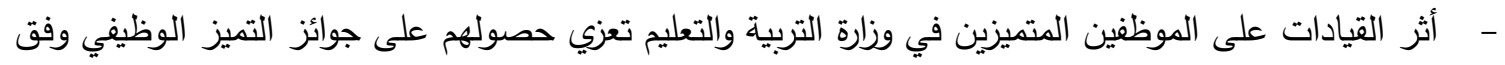
أبعاد أنموذج الإمارات للقيادة الحكومية: الروح القيادية، النظرة المستقبلية، التأثير والإنجاز

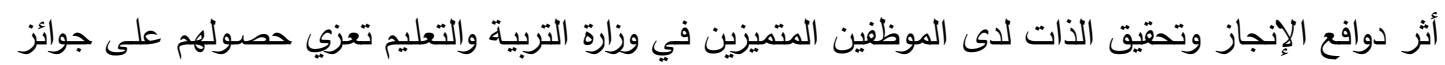
التميز الوظيفي وفق أبعاد الدوافع الداخلية والخارجية

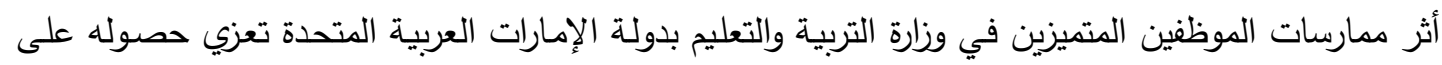

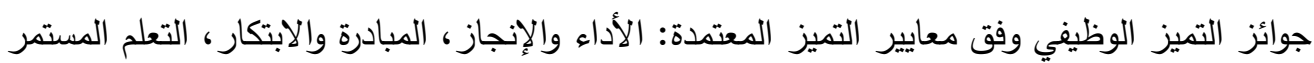

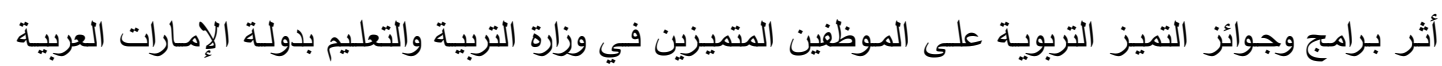
المتحدة تعزي حصولهم على جوائز التميز الوظيفي وفق أبعاد: أدوار إدارات الجوائز ، ملائمة معايير التميز . 1.3 أهداف الدراسة: تهدف هذه الدراسة إلى : 1.3 تحديد أدوار القيادات في تعزيز التميز الوظيفي لدى العاملين في وزارة التربية والتعليم بدولة الإمارات العربية المتحدة من خلال أبعاد القيادة: الروح القيادية، النظرة المستقبلية، التأثير والإنجاز إيجاد أثر دوافع الإنجاز وتحقيق الذات لدى الموظف المتميز في وزارة التربية والتعليم تعزي حصوله التهله على

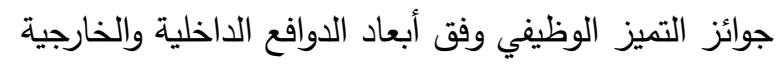
تحديد أثر ممارسات الموظف المتميز في وزارة التربية والتعليم بدولة الإمارات تعزي حصولية ولهاد على على جوائز التميز

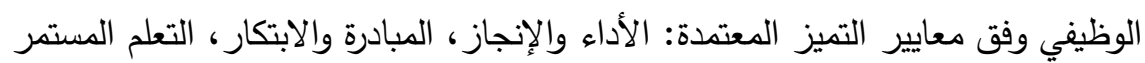

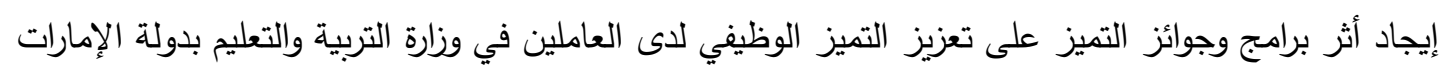

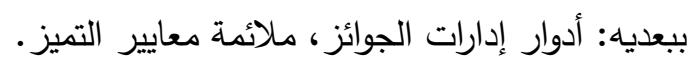

1.4

أ- القيمة العلمية: بالرغم من وفرة الدراسات حول التميز الوظيفي ومحفزات الموارد البشرية لتحسين الأداء؛ إلا أنه لم يتتاول الباحثين تأثير أدوار القيادات وتأثير الدوافع الذاتية في حصول الدورة الموظفين التئين المتميزين في وزارة

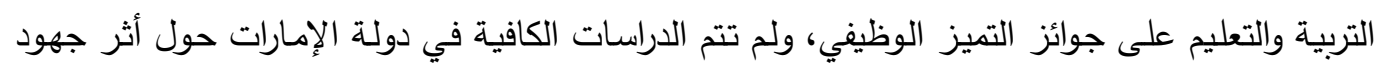

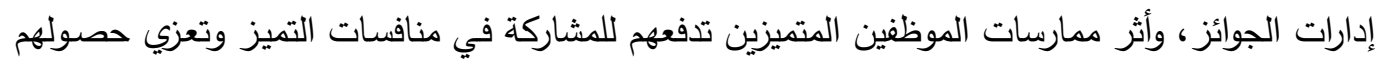
على الجوائز ، خاصة بوجود العديد من جوائز التميز في الدولة التي أفرزت مئات الموظفين التينين المتميزين في وزارة التربية والتعليم وذلك منذ عام 1995م بظهور أول جائزة تكرم العاملين المتميزين في التربية: جائزة الثارقة للتفوق والتميز التزبوي، وتلتها في عام 1998م جائزة حمدان بن راشد آل مكتوم للأداء التعليمي

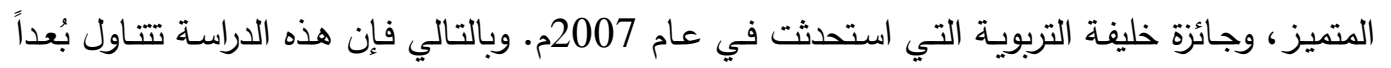

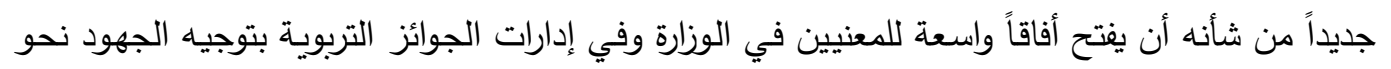


تعزيز وتمكين قدرات الموظفين وتحريك دوافهم نحو قيم الإنجاز ، وتمكين القيادات وإلهامها لتحفيز وتثجيع المتميزين للمشاركة في مختلف منافسات جوائز التميز الوظيفي محلياً وعالمياً.

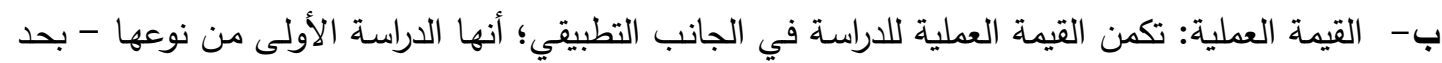
علم الباحث- التي تطبق على عينة الموظفين المتميزين في ثلاثة جوائز رئيسة تستهدف العاملين في وزارة

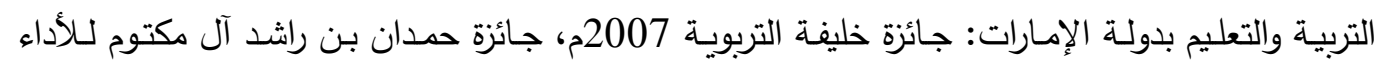
التعليمي المتميز 1998م، وجائزة الثارقة للتفوق والتميز التربوي 1995م. كما تتفرد الدراسة عند تطبيق لتربه متغيراتها المستقلة والمؤثرة على المتغير التابع وإيجار الأثر والترابط بينها من خـلال أنموذج الإمـارات

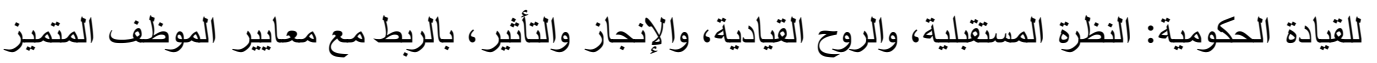

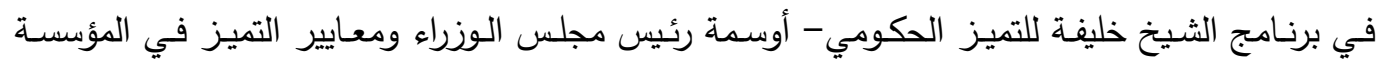
الأوروبيـة للجودة الثـاملة: الأداء والإنجاز ، المبادرة والابتكار ، التعلم المستمر ـ وبُعديّ دافعيـة الإنجاز

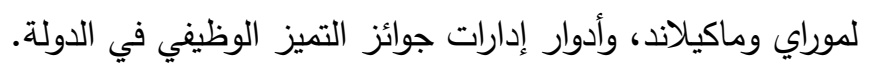

1.5 بناء على الدراسات السـابقة ذات العلاقة فإنـه يمكن تحديد عدد من الفرضيات البديلة (H1) على أنهات

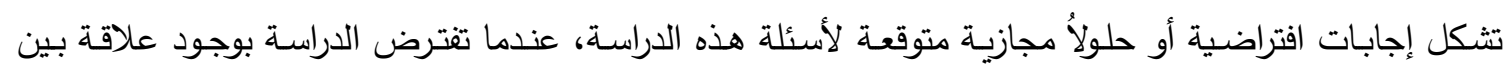

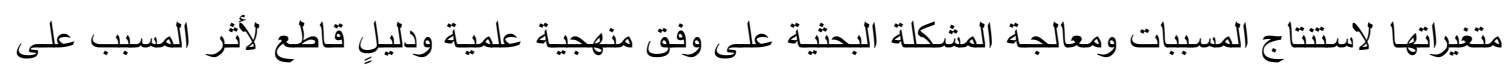
السبب، وذلك على النحو الآتي:

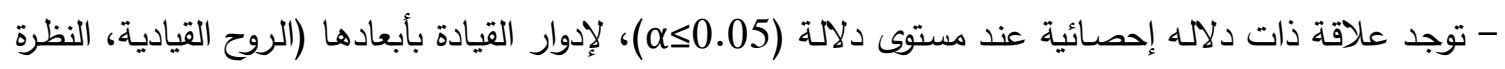
المستقبلية، التأثير والإنجاز) تعزي حصول الموظفين على جوائز التميّز الوظيفي في وزارة التربية والتعليم بدولة التهاتي الإمارات العربية المتحدة.

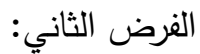

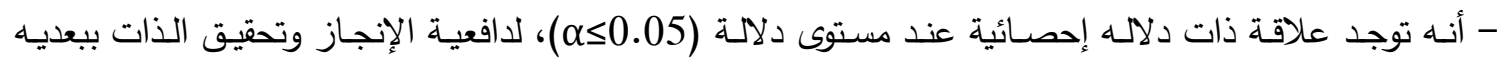

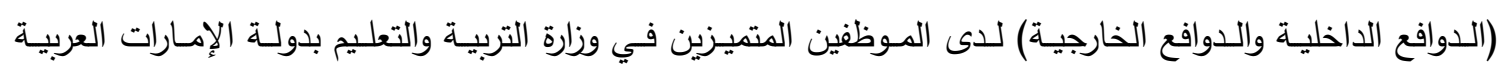
المتحدة، تعزي حصولهم على جوائز التميز الوظيفي.

- توجد علاقة ذات دلاله إحصائية عند مستوى دلالة (0.05 م)، لممارسات الموظف المتميز بأبعادها (الأداء

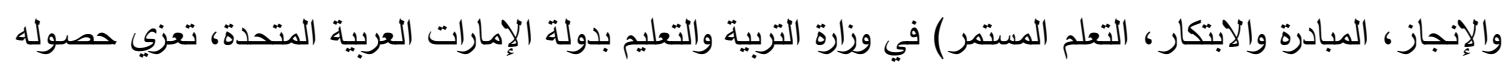
على جوائز التميز الوظيفي

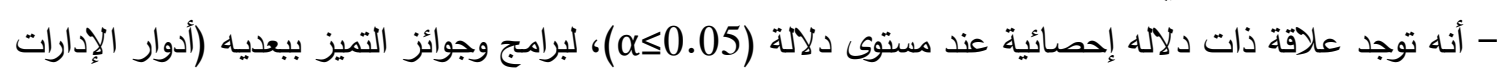

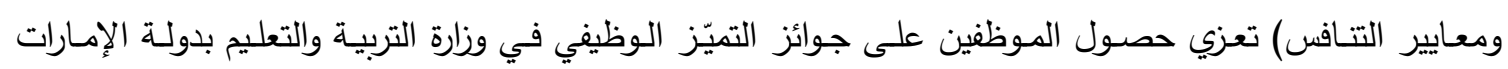
العربية المتحدة.

1.6 الدراسات السابقة تتباين آراء الباحثين ونتائج الدراسات ذات العلاقة بموضوع القيادة والتميز الوظيفي، وقد أسفر الأدب العربي

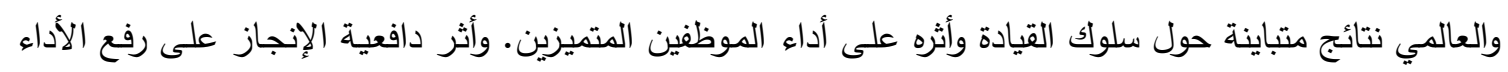
والانتاجية. ونلحظ أن هناك ندرة في الدراسات المتعلقة بجوائز التميز الوظيفي بثكلٍ عام. ولم ترد أي دراسة مطبقة 
على مجتمع وزارة التربية والتعليم بدولة الإمـارات، على عينـة الفائزين بثلاث جوائز رئيسة في الدولة، كما لم ترد

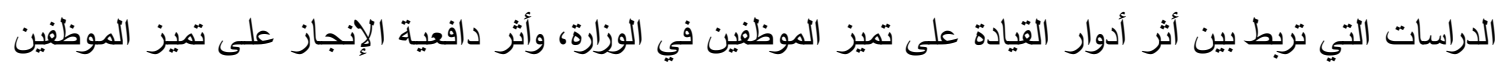
وحصولهم على أحد الجوائز المعتمدة.

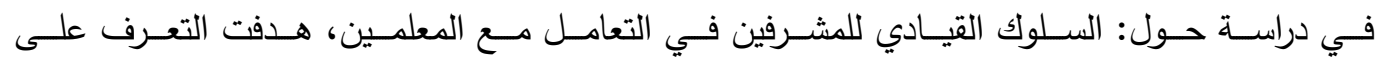

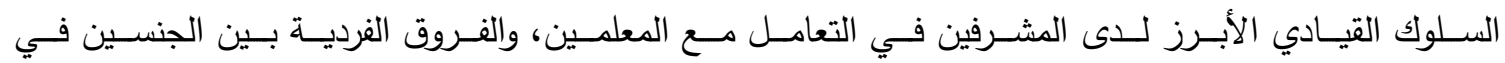

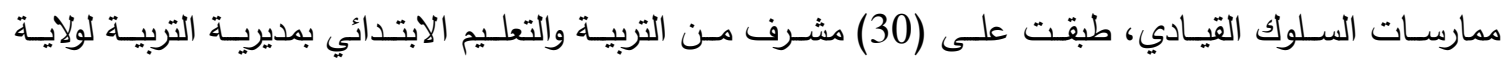

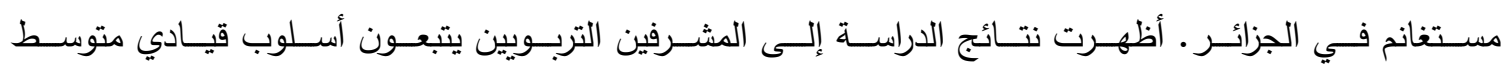

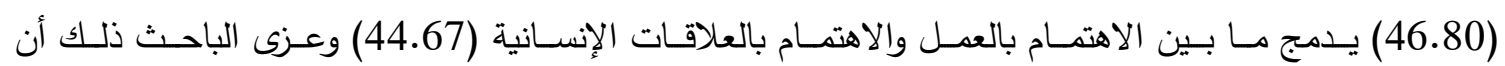

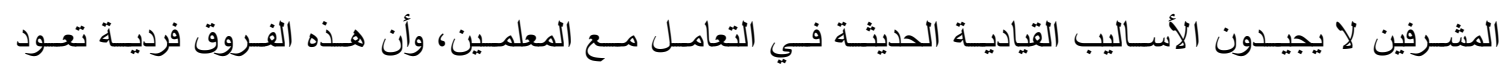

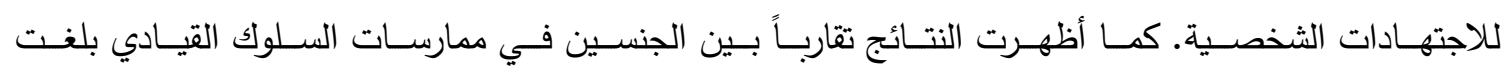

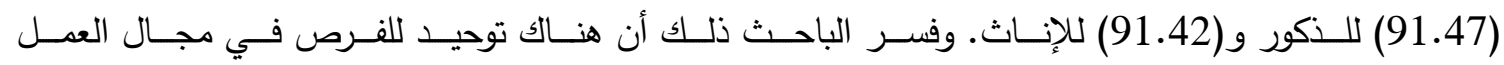

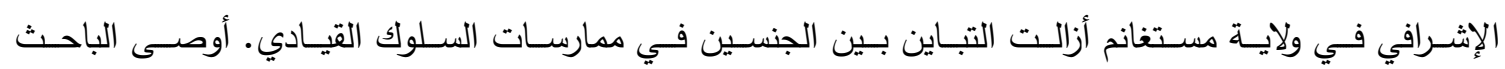

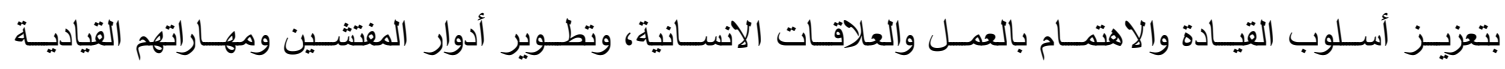

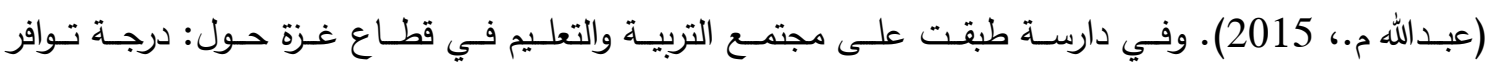

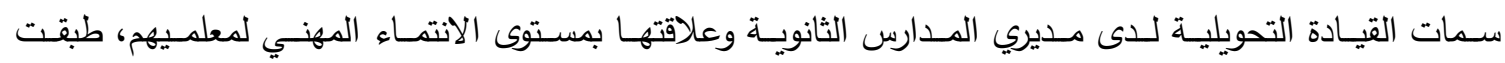

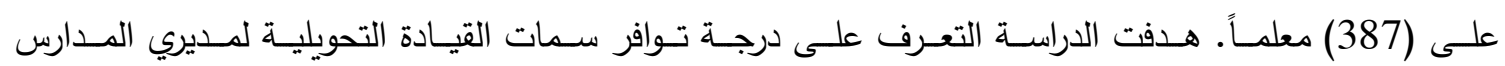

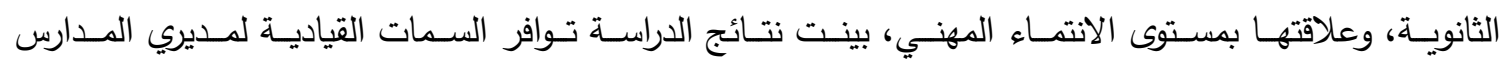

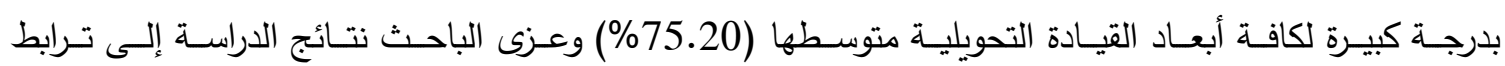

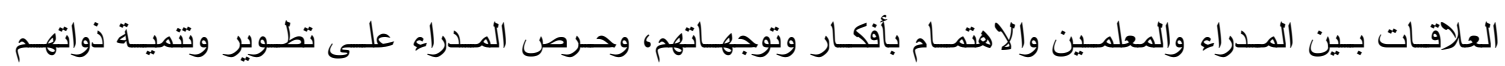

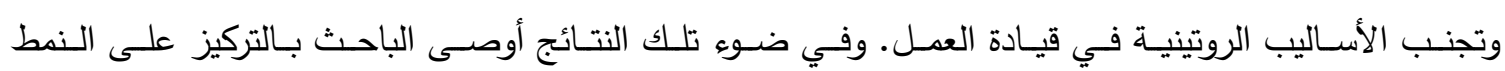
القيادي في ممارسات القيادات التربوية، والتشجيع والتكريم الدوري للمتميزين (عبدالعال، 2016).

فـي الدراسـات المتعلقـة بتـأثير القيـادة علـى دافعيـة الإنجـاز وأداء المـوظفين، دراســة: الــمط القيـادي للمـدراء

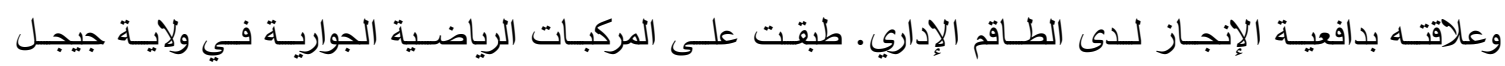

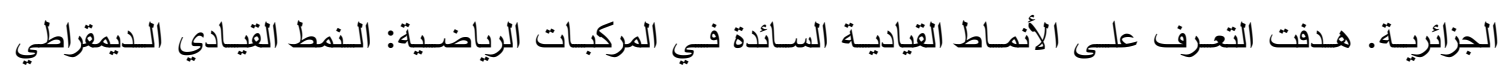

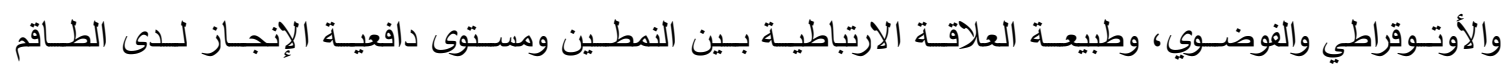

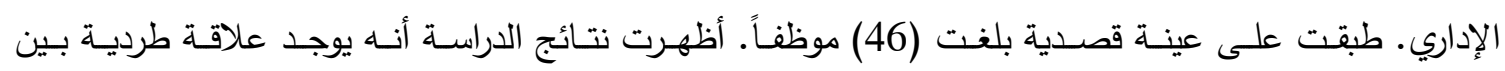

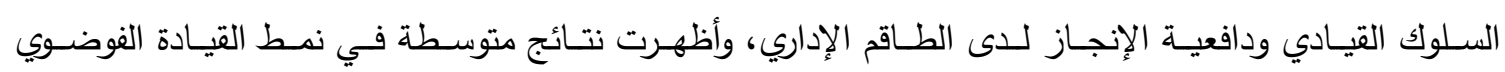

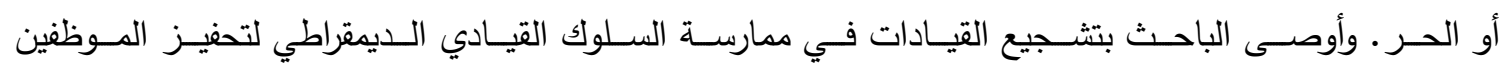

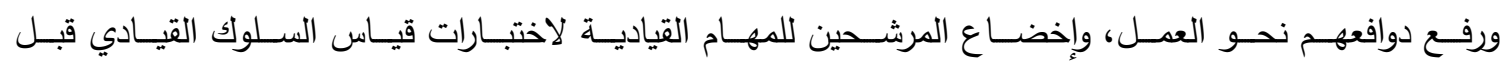

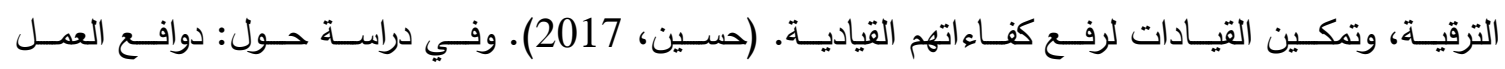

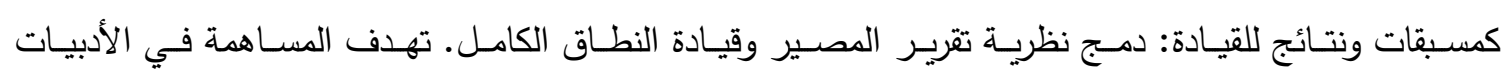

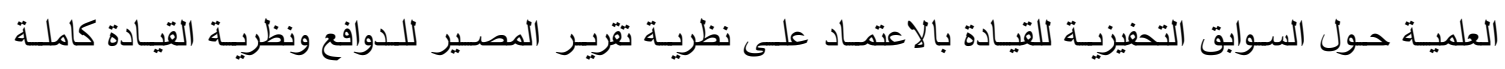

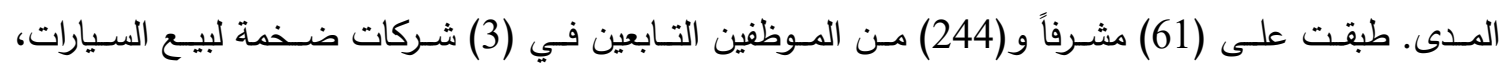

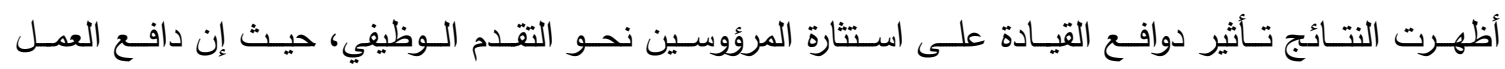




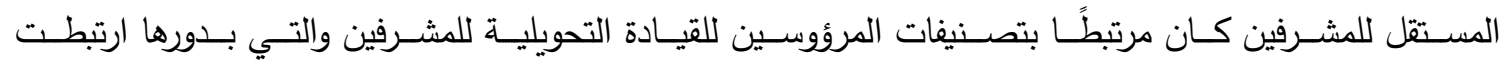

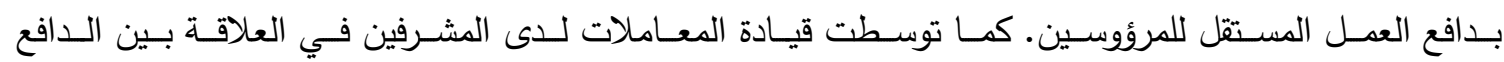

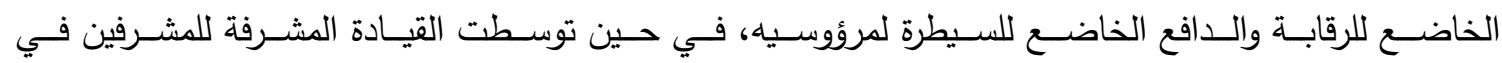

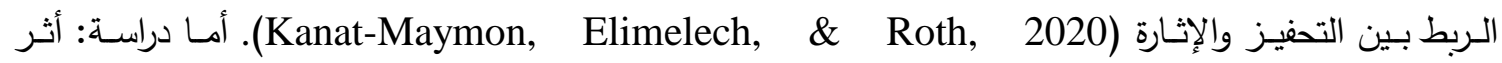

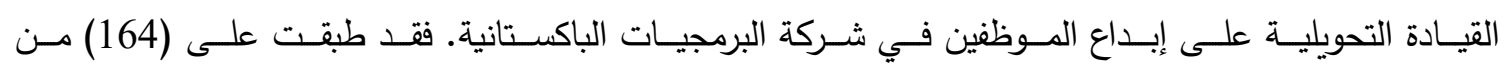

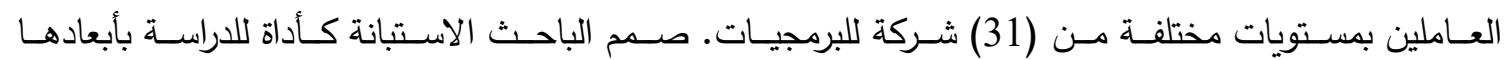

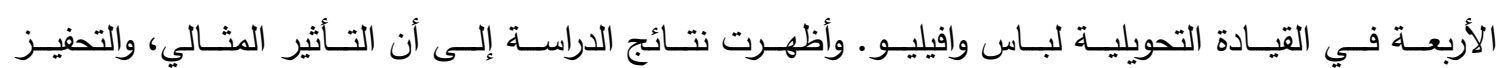

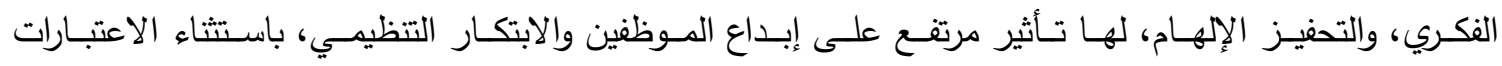

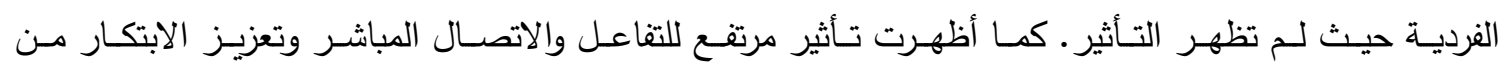

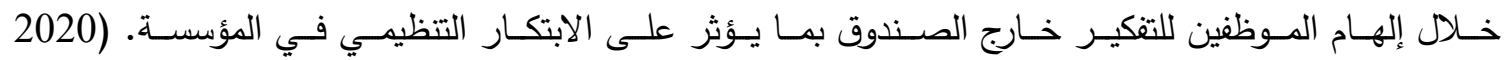
.(Shafi, Song, \& Sarker,

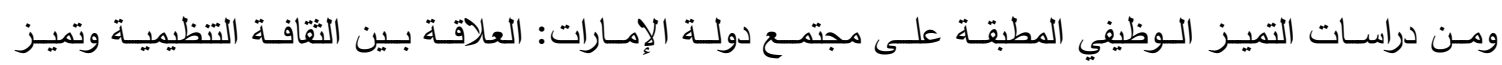

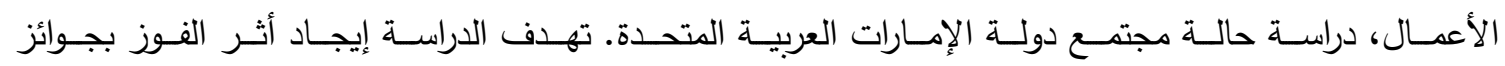

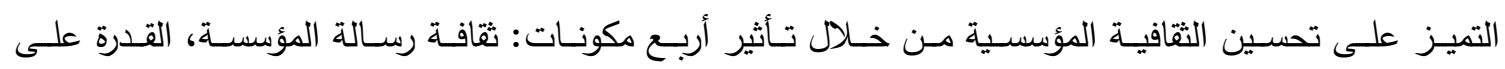

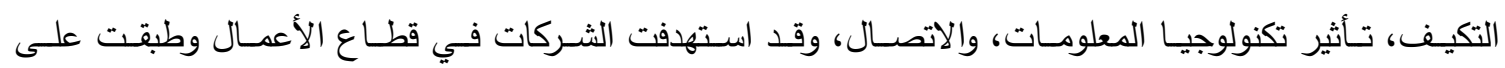

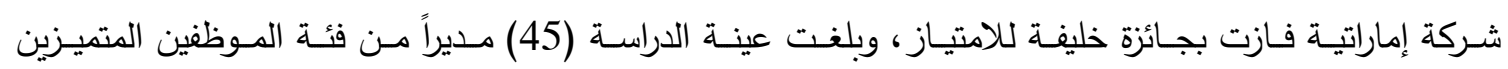

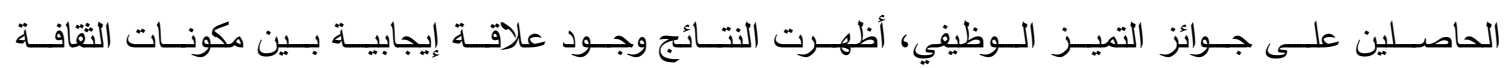

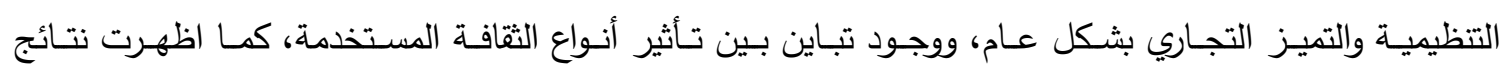

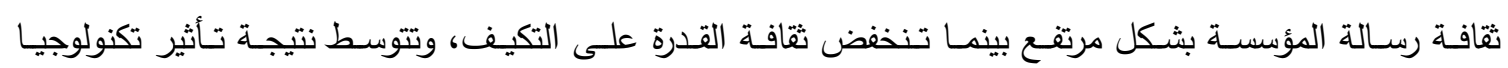

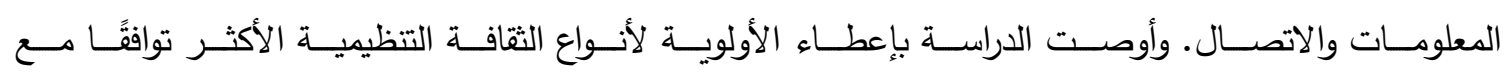

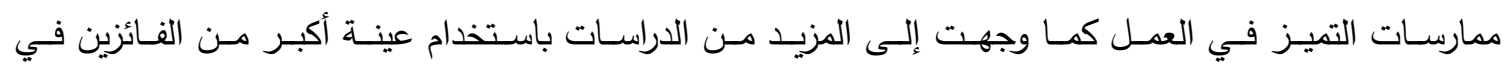
الجوائز ، وقوائم جوائز أخرى. (Rassel Kassem, Ajmal, \& Khan, 2016). ودراسـة القايدي

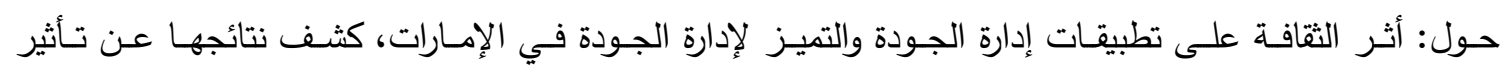

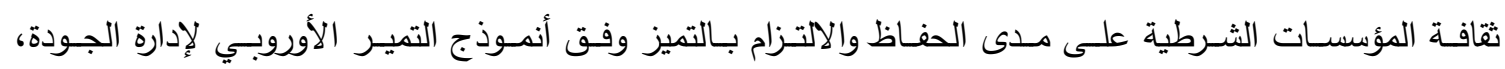

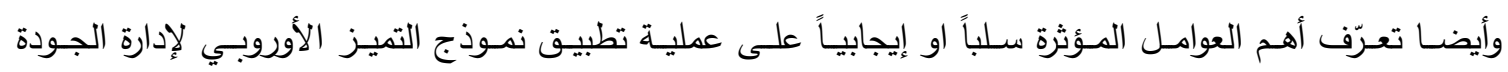

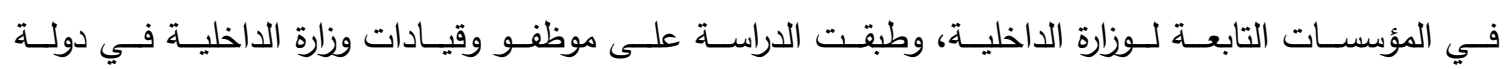

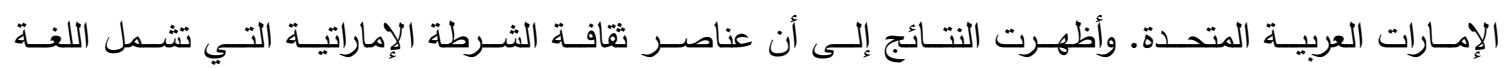

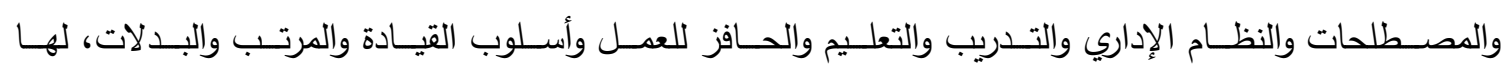

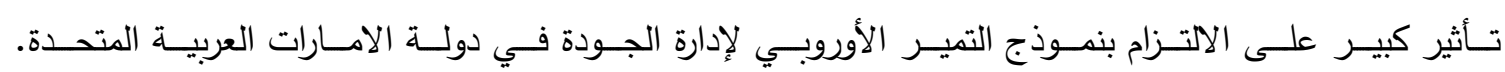

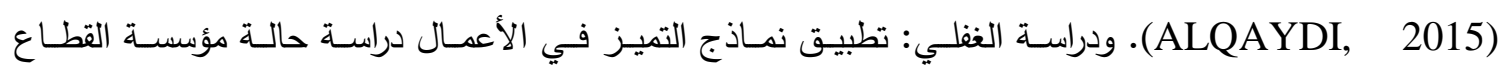

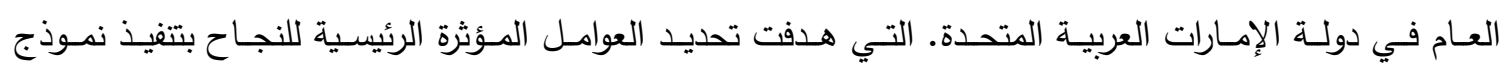

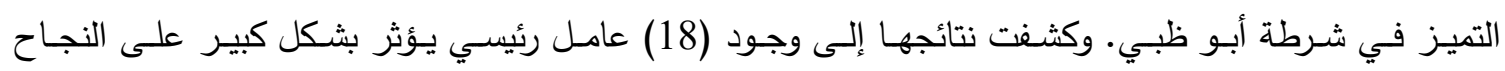
في تتفيذ نموذج تميز الأعمال (GHUFLI, 2012). 


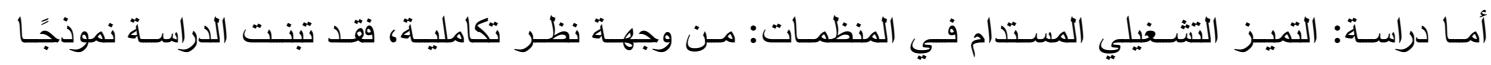

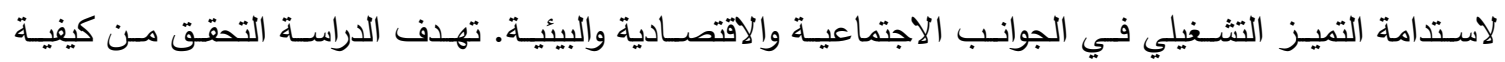

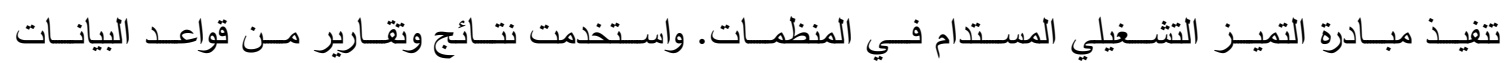

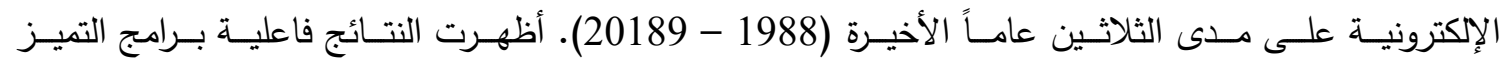

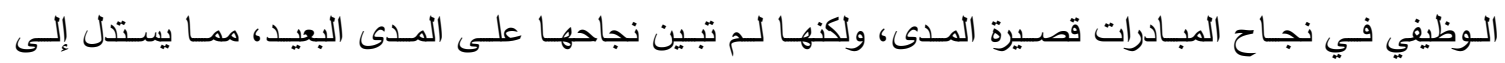

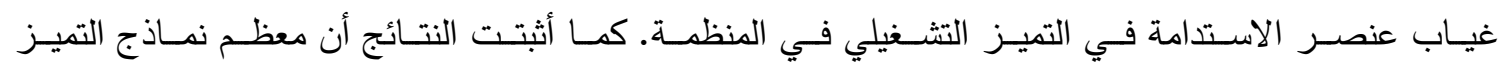

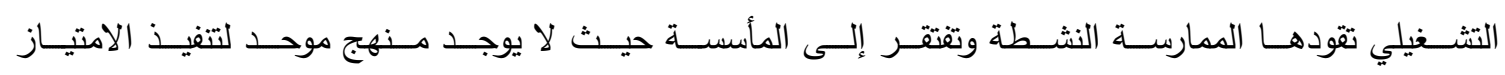

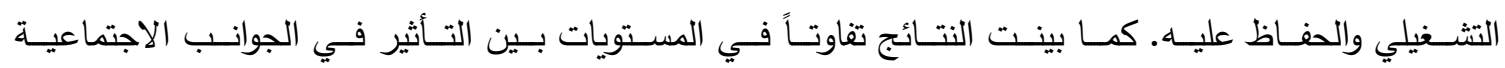

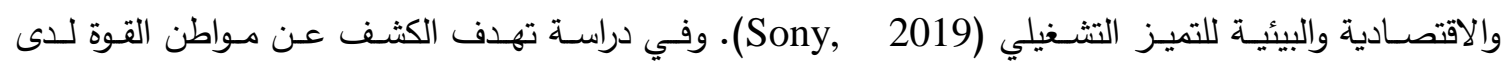

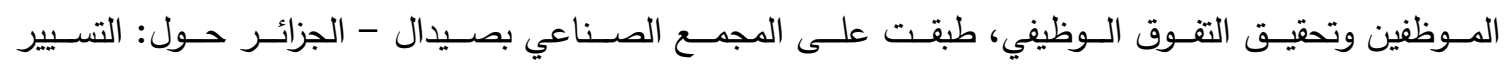

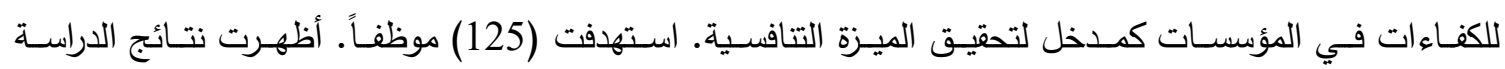

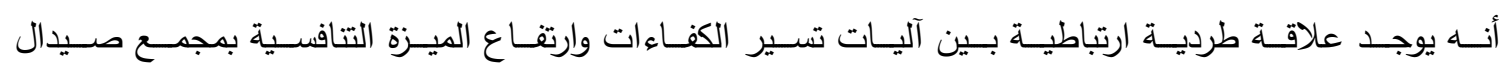

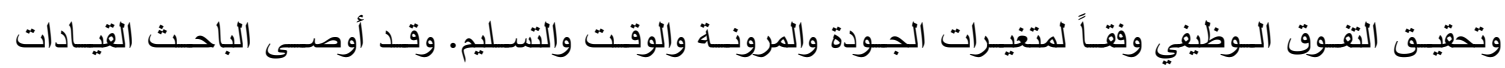

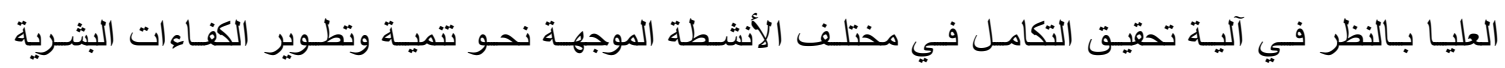

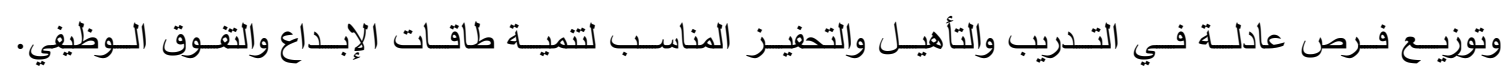

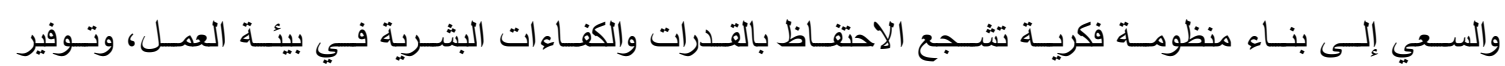
العناية للازمة بالعنصر البشري. (بوزناق، 2020).

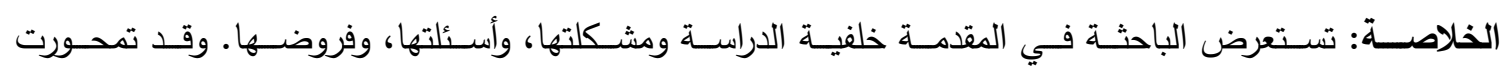

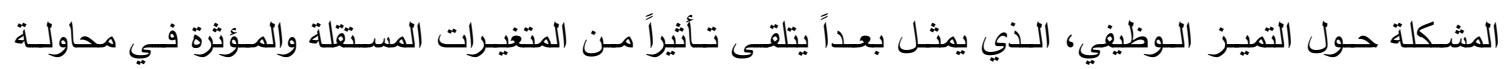

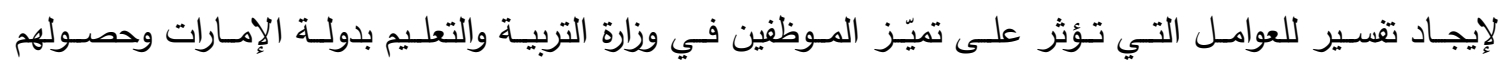

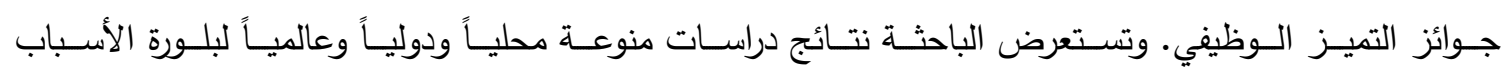

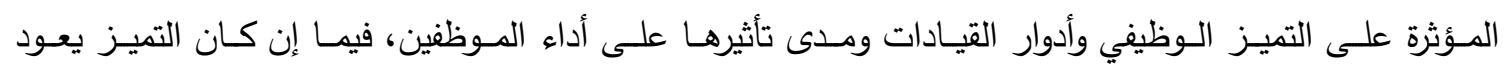

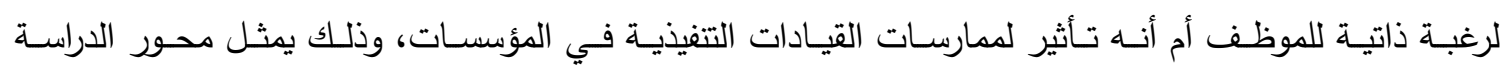

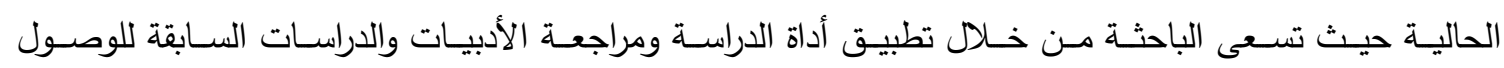
إلى نتيجة تتوافق مع أو تقسر اهتمامات العالم وتوجهات الدولة نحو تقدير وتعزيز رأس المال البشري.

الإطار النظري

\section{1}

برز الاهتمام بالموارد البشرية في العصر الحديث نتيجة التطورات الهائلة في مختلف تقتيـات الحياة، والتسارع الهائل في علوم التكنولوجيا، ما أدى إلى تحولات جذرية في الدفاهيم الإدارية المؤسسية والهياكل التظظيمية،

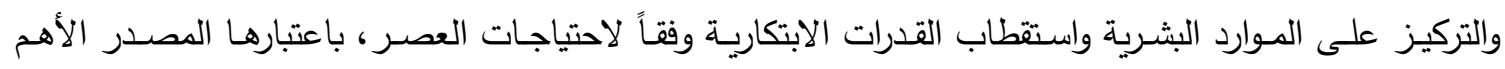

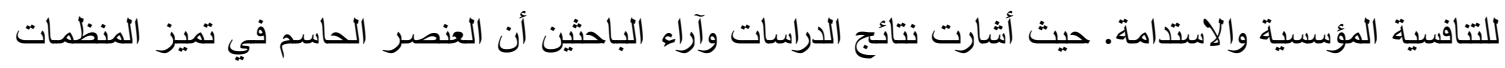
وتحقيق التفوق وكفاءة الانتاج تتمثل في تطوير وتنمية الموارد البشرية والاحتفاظ بالقدرات الموهوبة والمتميزة في بيئة العمل. وبذلك تمثل مرحلة القرن العشرين بدايات التحول في لإدارات الموارد البشرية من إدارة شؤون الأفراد إلى إدارة 
الموارد البشرية أو إدارة رأس المال البشري، بتسليط الضوه على الممارسات الحديثة في التتمية والتطوير والتمكين

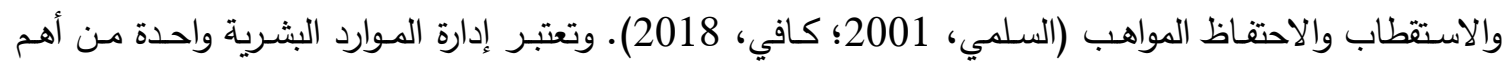

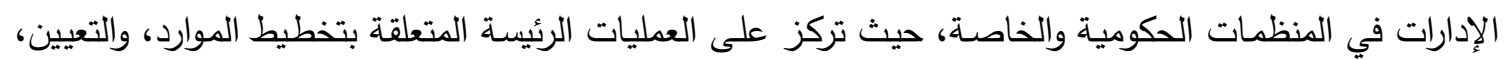
والتقييم، والتطوير والتتمية، وغيرها من الوظائف التي تعكس الثمولية والتكامل في توزيع المهام وتوصيفها في هيكل

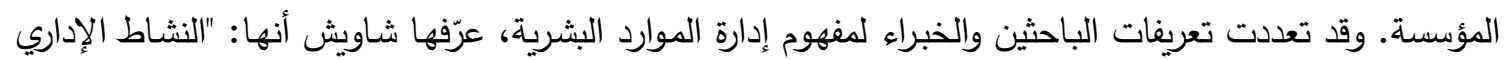
المتعلق بتحديد احتياجات المشروع من القوى العاملة، وتوفيرها بالأعداد والكفاءات المحددة، وتتسيق الاستفادة من

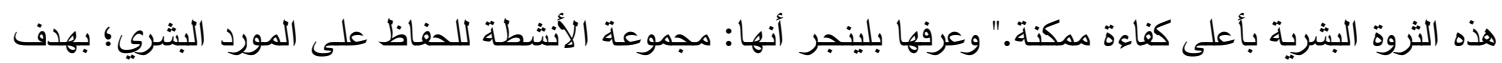

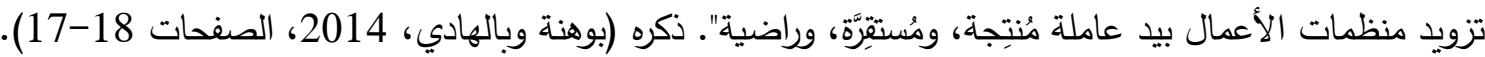

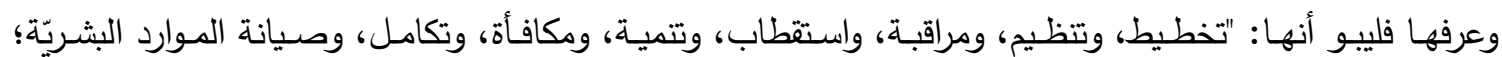
لغرض تحقيق أهداف المُنظَّمة" (حنفي، 2010). كما عرفها (كداو، 2016، صفحة 13 1) أنها: نموذج متميز لإدارة البشر لتحقيق الميزة التتافسية من خلال صياغة استراتيجيات التحول إلى الكفاءة والولاء المؤسسي". أما السلمي فقد

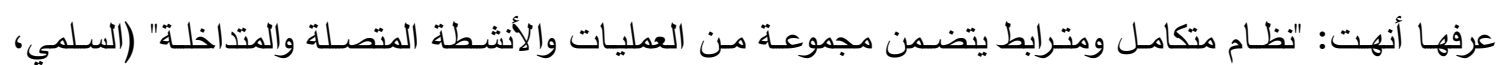
.(2001

\section{2}

تؤكد النظريات العلمية والدراسات الحديثة في مجال الجودة والتميز الوظيفي، أن التميز صفة مكتسبة،

وأنها ترتبط بعدد من المثيرات الداخلية والخارجية وتعزز دوافع ذاتية للموظف لتحقق له نشوة وسعادة محددة عند

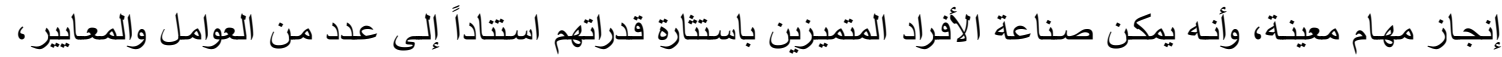
كالتحفيز والتقدير والتدريب والتأهيل المهني والتخصصي (البارودي، 2016). وتثـير الأدبيات إلى أن الوظيفة منصب خدمي في المؤسسات بمختلف المستويات، يعود إلى الفعل وظظَّف، أي أُسند إليه عملاً، أو عينه للقيام بمهام

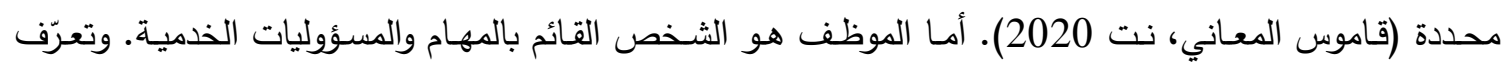
الوظيفة بمجموعة المسؤوليات والواجبات الرسمية في هيكل المؤسسة، والتي تتطلب تعيين وتحديد شخص ما للقيام

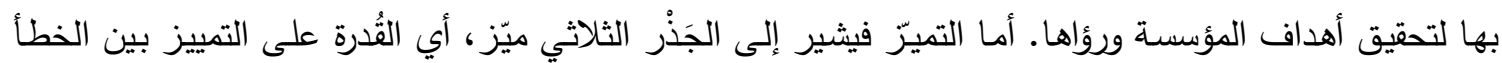

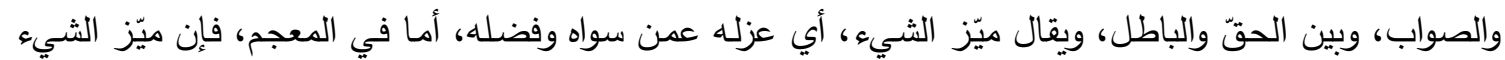

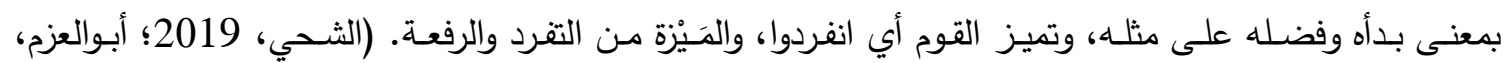

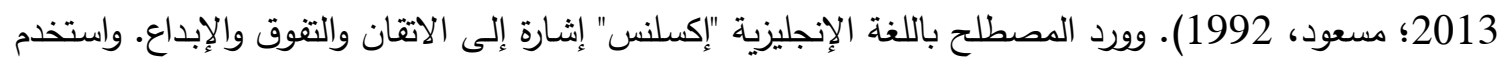
المفهوم عند الإغريق للدلالة على أفضل الأحوال. ويشير العديد من الباحثين إلى أن التمّيز لا يعني فقط التقوق بل التهل

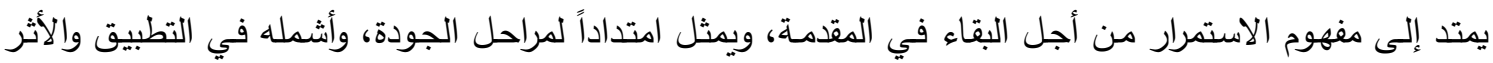
المترتب على الأداء. وهذا ما أكد عليه الثيخ محمد بن راشد آل مكتوم نائب رئيس الدولة رئيس مجلس الوزراء

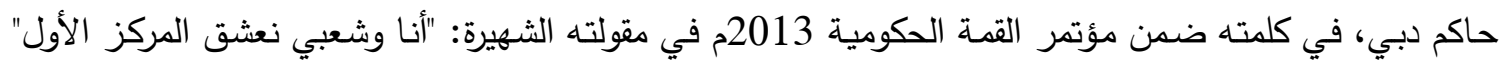

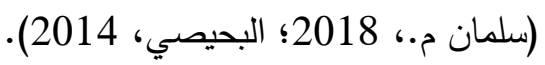

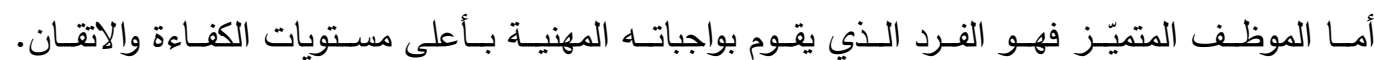

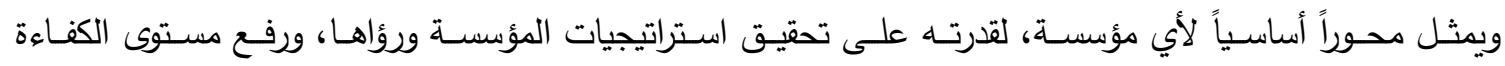

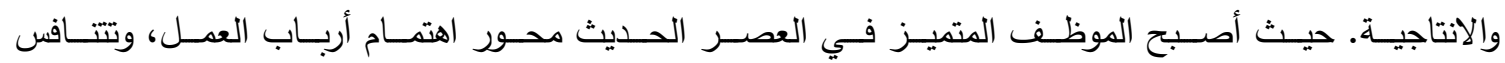

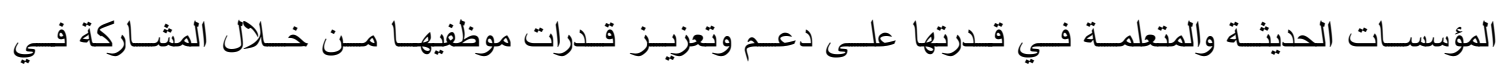




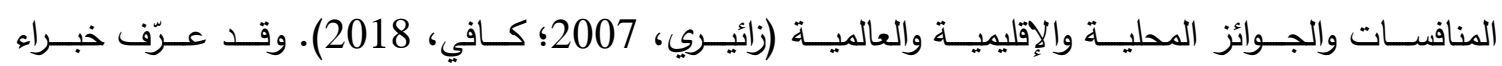

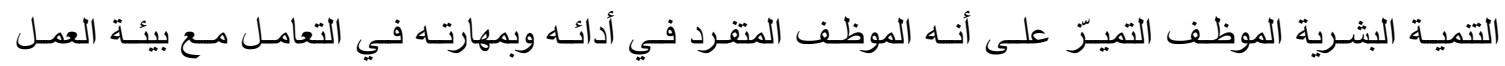
بمقدار يفوق ويتعدى الواجبـات الأساسية المدونـة في بطاقـة الوصـف الـوظيفي. ويمثل التميـز الوظيفي قـراراً

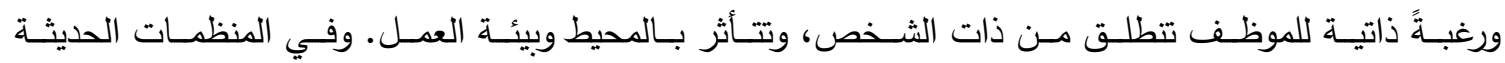

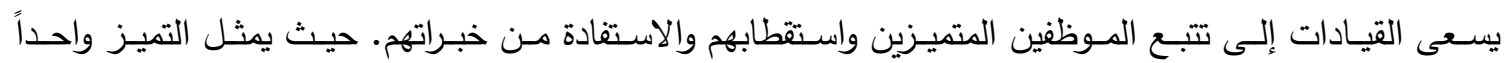

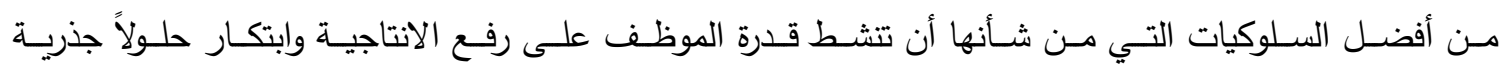

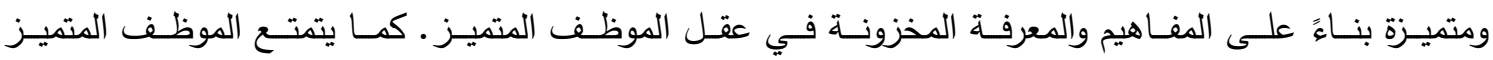

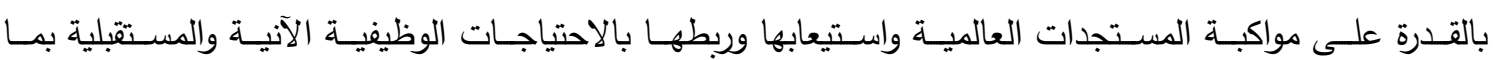
يعود على التميز المؤسسي (النصيرات، 2018).

2.3 جوائز التميز الوظيفي في دولة الإمارات العربية المتحدة

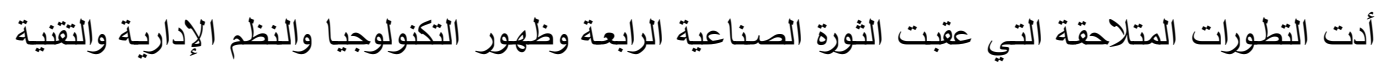
الحديثة، إلى تغيرات جذرية في نمط إدارة الأعمال في القطاعين العام والخاص. حيث تعقدت طبيعة العمل وتشعبت التبات الأدوار المنوطة بالمؤسسات وأصبح أرباب الأعمال غير قادرين على مواجهة التحديات دون التركيز على مواهب

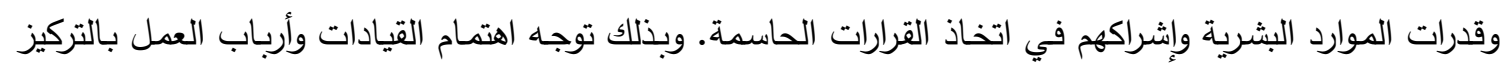
على العنصر البشري لضمان استمرارية نجاح المنظمات. فعملت مؤسسات القطاع الحكومي على تعزيز القدرات

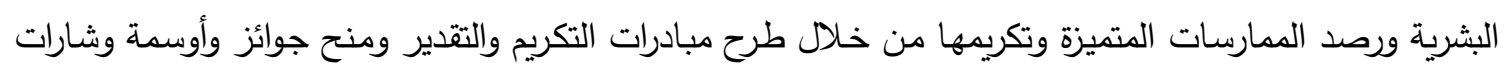

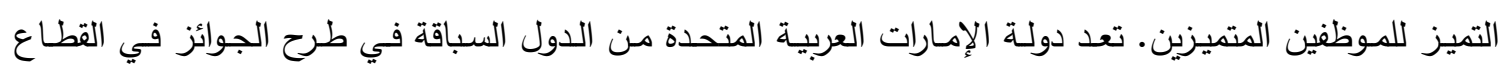
الحكومي، وقدمت خـلال المدة الزمنيـة مـن 1995 إلى 2020م نمـاذج منوعـة ومميزة مـن برامج وجـوائز التميز

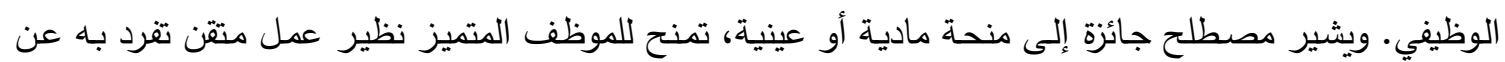

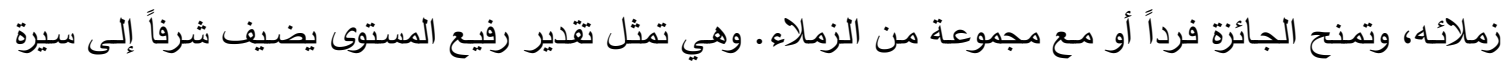

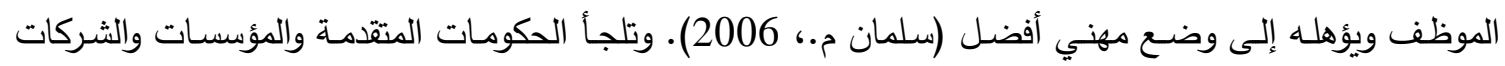

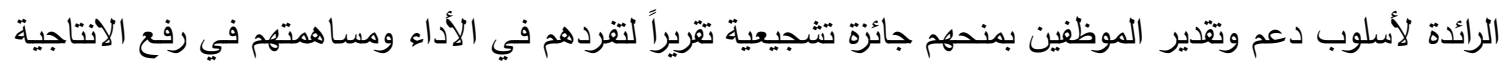

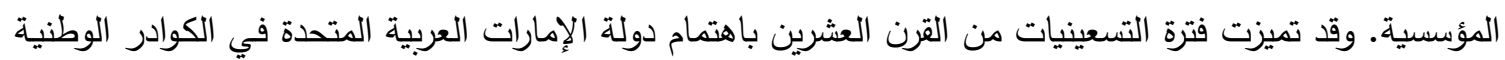
باعتبارهـا رأس المال البشري لإدارة شؤون الهيئات والمؤسسات الحكوميـة بكفاءة وفاعلية، والقوى المحركة للتميز

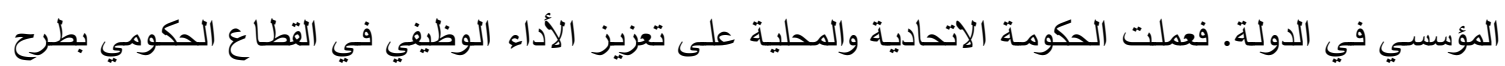
مبادرات التمكين والتحفيز ووضعت استراتيجيات وسياسات تطوير وتتميـة الكوادر الوطنية والاهتمام برأس المسال البشري واستثمار القدرات، من أمثلة برامج والجوائز التميز :

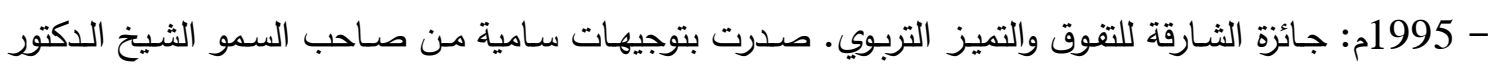

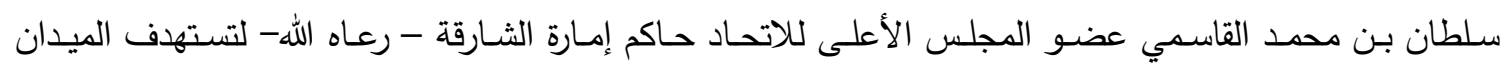
التعليمي بمختلف شرائحه وفئاته في العام الدراسي 1995 - 1994م، وبذلك تمثل أول جائزة تربويـة تستهدف الطلبة الفائقين في مدارس منطقة الثارقة التعليمية. وفي العام الدراسي 2002 - 2001م تطورت في فئاتها لتشمل

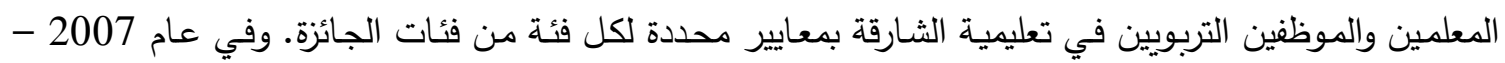
2006م توسعت في نطاقها الجغرافي لتشمل الموظفين والتربويين على مستوى الدولة. وتوسعت في فئاتها لتراعي 
التتافس الفردي والجمعي في أغلب التخصصـات في الميدان التربوي (جـائزة الثـارقة للتفوق والتميّز التربوي، .$(2020$

- 1998م: جائزة حمدان بن راشد آل مكتوم للأداء التعليمي المتميز : انطلقت الجائزة في عام 1998م على مستوى

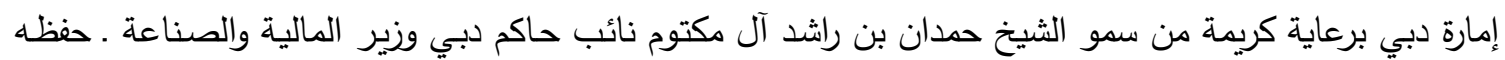

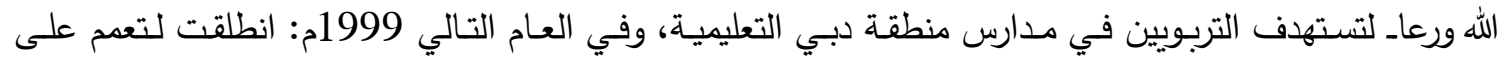
مدارس الدولة كافة، لترتقي بالأداء التعليمي في كافة مراحل وقطاعات وزارة التربية والتعليم. وتمثل جائزة حمدان

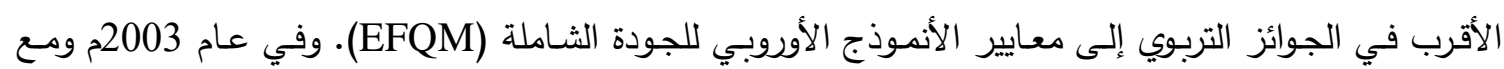
انتهاء فعاليات الدورة الخامسة عمدت الجائزة على دول مجلس التعاون الخليجي في فئات الطالب المتميز والمعلم المتميز والمدرسة والإدارة المدرسية المتميزة. (جائزة حمدان بن راشد آل مكتوم للأداء التعليمي المتميز ،

- 2007م: جائزة خليفة التربوية: انطلت الجائزة برعاية سامية دن صاحب السمو الثيخ خليفة بن زايد آل نهيان، رئيس الدولة - حفظه الله ورعاه. وبتوجيهات كريمة من سمو الثيخ محمد بن زايد ولي عهد أبو ظبي نائب القائد

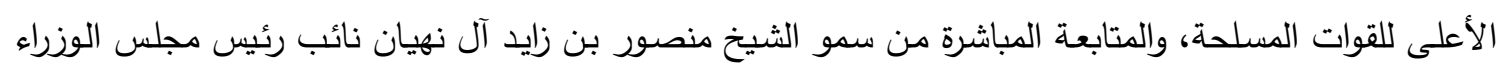

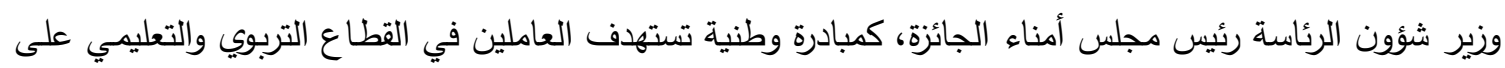

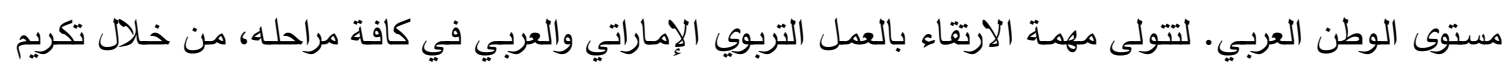

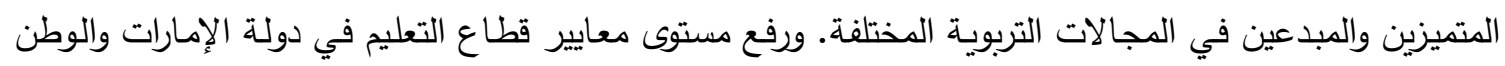

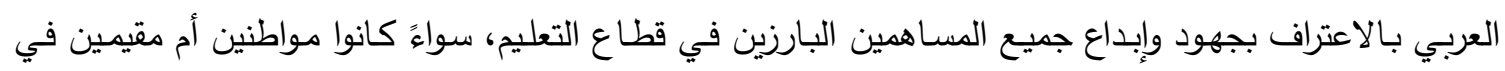
الدولة (جائزة خليفة التربوية، 2020).

2.4

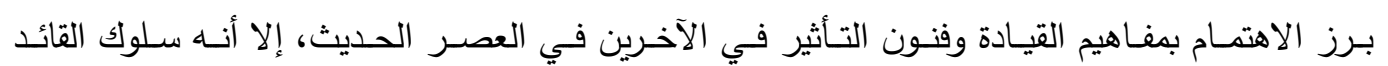

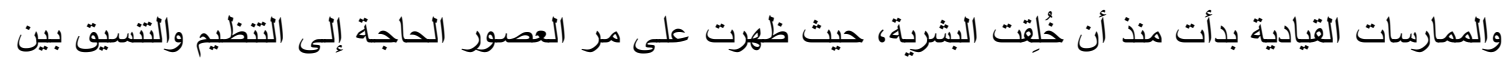

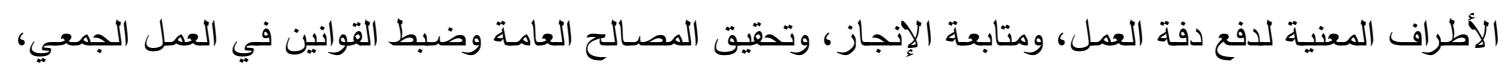

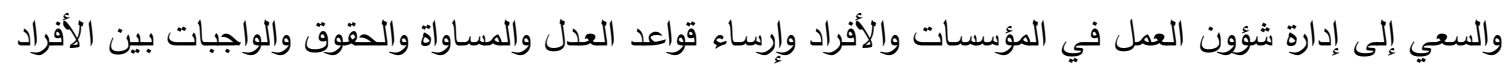

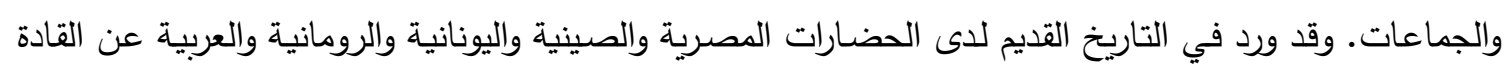
الأكفاء، قبل أن يصل مفهوم القيادة إلى الفكر التقليدي الحديث. وتأسست وأغلب مبادئ الإدارة التتظيمية الحديثة

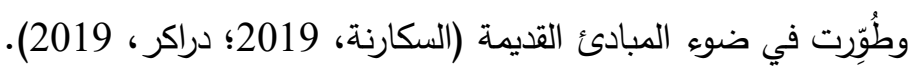
القيادة لغةً: مصدر من الفعل قاد يقود قوداً والقود نقيض السوق، ويقال يقود الدابة من أمادها، ويسوقها من الخلف.

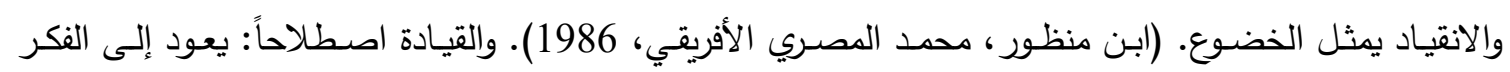

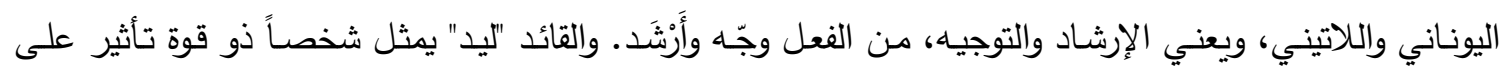

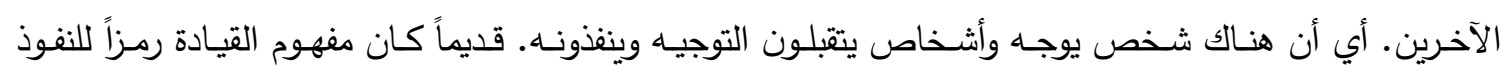

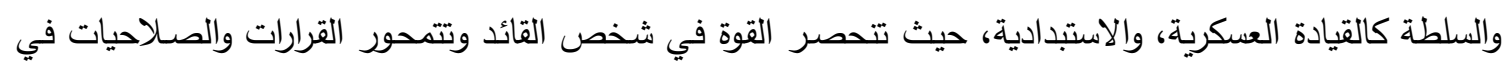
شخصـه. وفي العصر الحديث يرمز المصطلح إلى منصب ذو سلطة قانونية تشريعية، يمارس من خلالها القائد

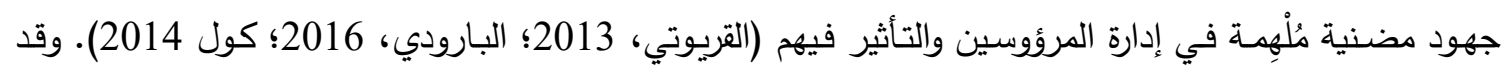
برز مفهوم القيادة المحفزة ورعاية مصالح العاملين وتقديرهم ومكافأتهم بهدف تحقيق أهداف المؤسسة بعد أن كان 
الاعتقاد أن القوة والتهديد سبيلاً للإنجاز وتحقيق غايات المؤسسة (كامب، 2000، صفحة 29، 30). واليوم يقاس تقدم الحكومـات على مدى اهتمامها بتطوير القيـادات وفق منـاهج ومـارس معتمدة عالميـاً (مـاكجراث، 2019؛

(Maxwell, 2019

تعددت تعريفات القيادة بتعدد وجهات نظر الكتاب المختصين والباحثين في العلوم الإداريـة والممارسين لمفهوم السلطة، حيث ينظر للمفهوم من خـلال عدسة المناهج الفكرية والمدارس الثقافية والتخصصـات المختلفة، وكذلك فئك المهام المنوطة بالقائد، وبالتالي يختلف المفهوم لدى المؤرخين والباحثين في العلوم الإدارية عن مفهوم الممارسين في

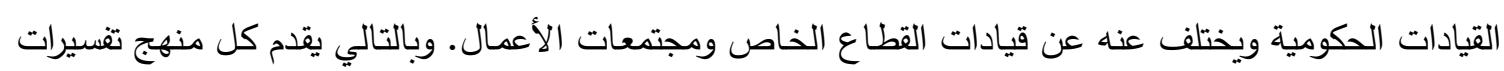
وتعريفات مختلفة. إلاّ أن أغلب التعريفات تتمحور حول مفهوم العلاقة بين طرفين، والقدرة على التأثير في الآخرين بأي شكل من أشكال التتظيم الإداري (بيندليتون و آدراين، 2019؛ الهواري، 2014). ويرجع الإن الفضل في تحليل فكر

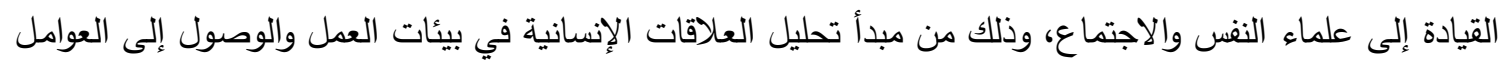

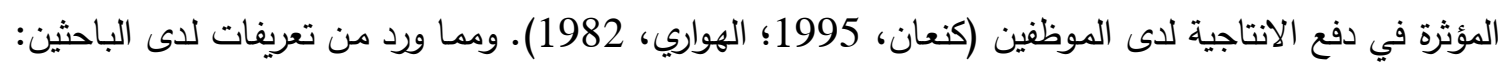
لخص جون سي ماكسويل في كتابه (تطوير القائد بداخلك)، مفهوم القيادة في عشرة أساسيات، بدأها بكلمة (التأثير)

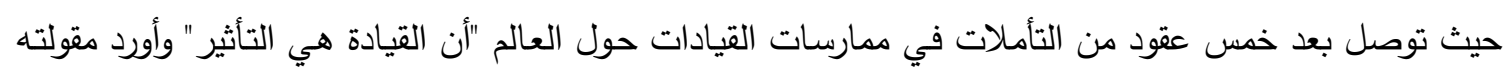

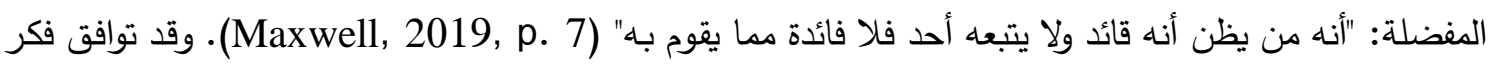

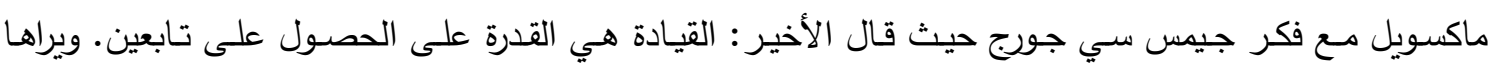

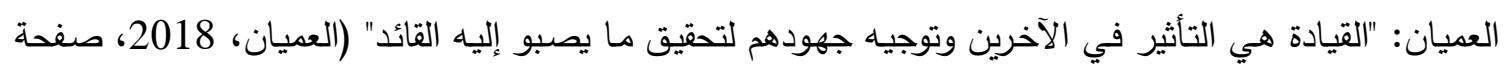
257). واعتبر بعض الباحثين القيادة نشاط ومسؤولية وشغف لبذل المزيد من العطاء؛ قبل أن تكون مهنة ووظيفة

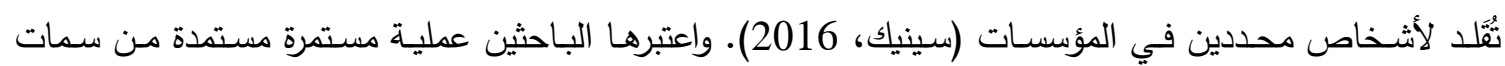

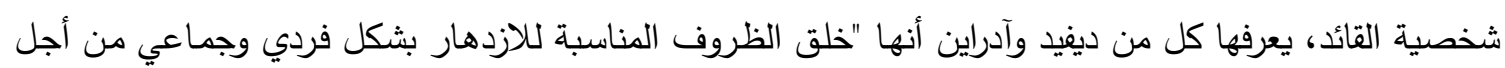

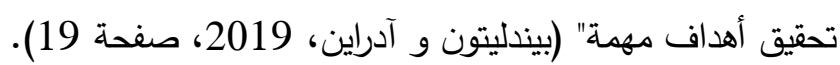

2.6

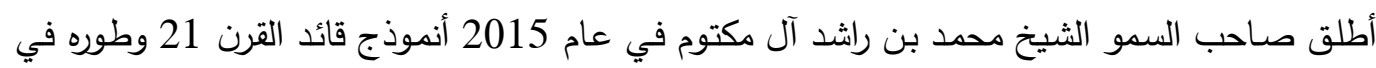
عام 2018 إلى أنموذج الإمارات للقيادة الحكومية. وقد طور الأنموذج وفق توجهات الحكومة بعد الاطلاع على فلى دأل

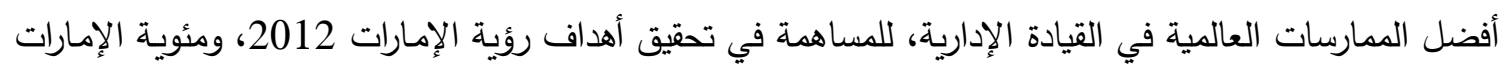

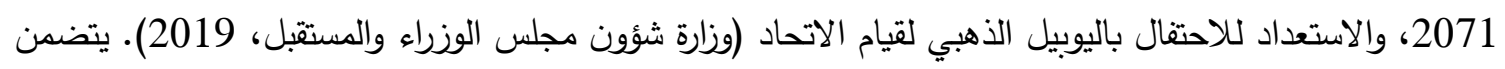
الأنموذج محاور رئيسة تثمل سمات القائد الملهم في حكومية دولة الإمارات، وتتمثل في: الروح القيادية، والنظرة المستقبلية، والإنجاز والتأثير حيث يعبر بُعد الروح القيادية عن: القائد مئكَن للإنسان، والقائد قدوة حسنة وتئة، والقائدائد منفتح على العالم. ويعبر بُعد النظرة المستقبلية عن: القائد الحكومي مستشرف للمستقبل، القائد الحكومي مبتكر لِّر ومحفز للتغيير القائد الحكومي ملم بتكنولوجيا المستقبل المتقدمة، والقائد الحكومي متعلم باستمرار ومدى الحياة.

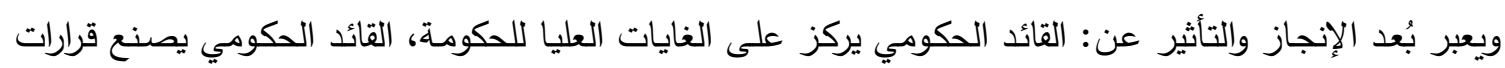
ذكية وفعالة، والقائد الحكومي مرن وسريع الاستجابة. ويهدف الأنموذج إلى تعزيز جهود حكومة الإمارات لمواكبة

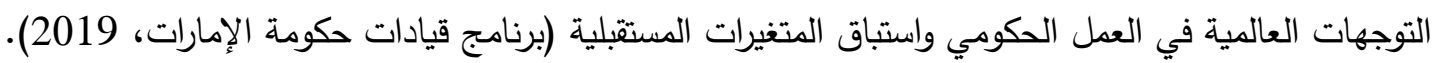




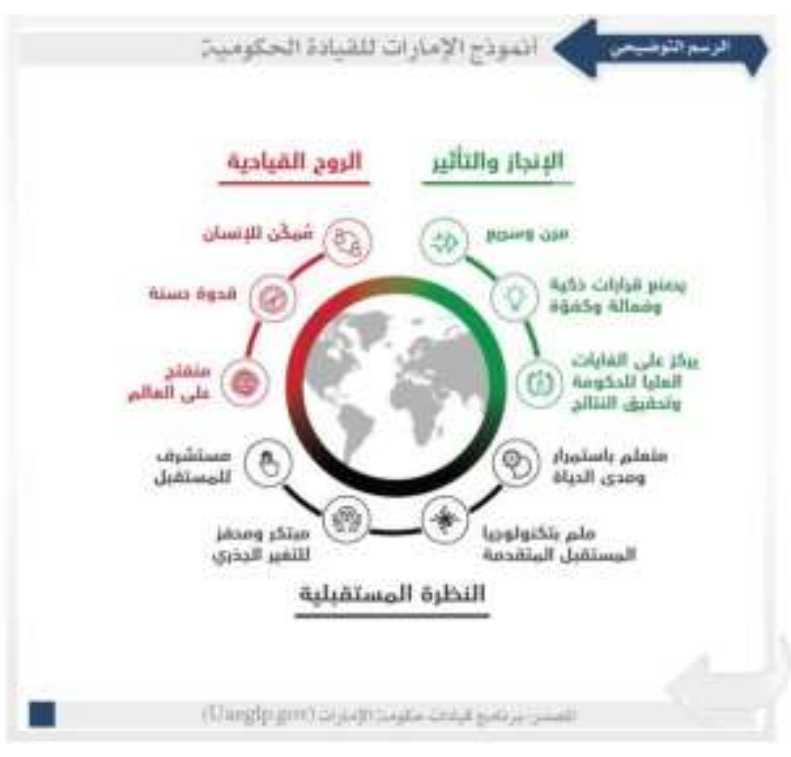

2.5

يمثل سلوك الإنسان وسماته الثخصية محور اهتمام الباحثين في العلوم الاجتماعية والسلوكية، وقد فسرت

الدراسـات والأبحاث سلوك البشر في مختلف المواقف الحياتيـة، وضدن الاهتمـام بالقيادة الإداريـة ومفاهيم الإدارة

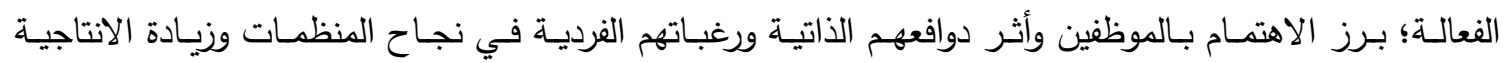

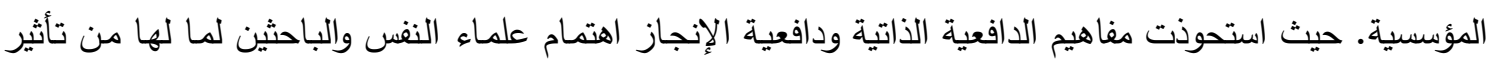
شامل على دفع الفرد نحو تحقيق أهداف محددة بثغف وهمة أكبر من المتوقع عند غياب الدوافع الذاتية. ويعتبر

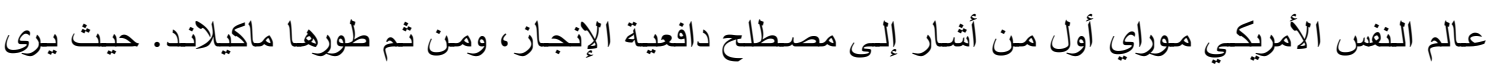

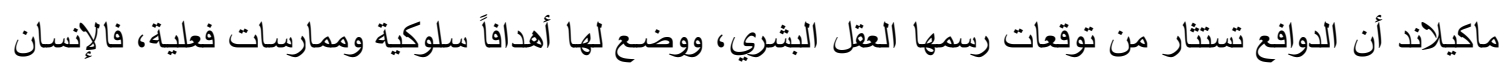
يسعى نحو تحقيق الأهداف التي سبق لـه أن عرف أنها تثير لذة لديـه. وبالتالي تعتبر : " كل الدوافع متعلمـة.

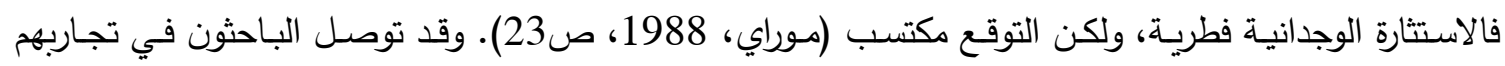

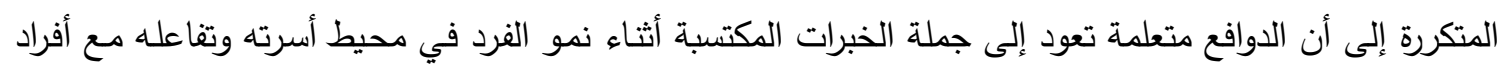

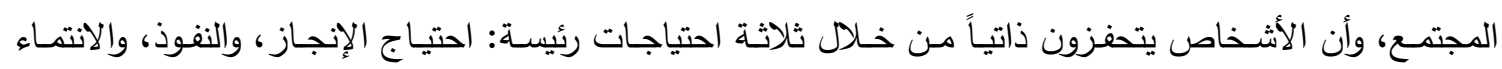
(ماكجراث وبايتس، 2019؛ بيرنز ، 2018).

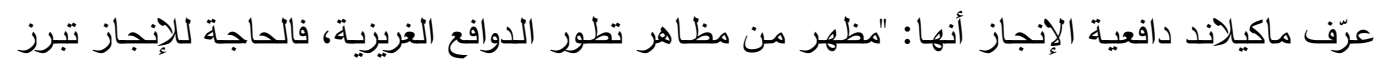

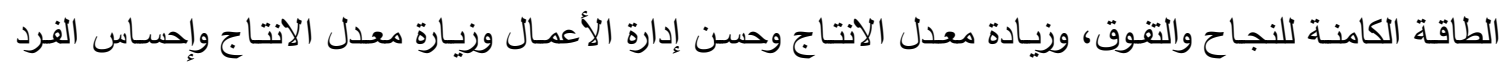
بالنجاح والتفوق في مجال عمله" (الرابغي، 2015، صفحة 156). وهي: "حالة داخلية أو خارجية تحث الفرد نحو الوصول إلى هدف معين" (أبوجودة، 2019، صفحة 47). ووردت لدى منصور زاهي تعريف كل من ماريو وليام

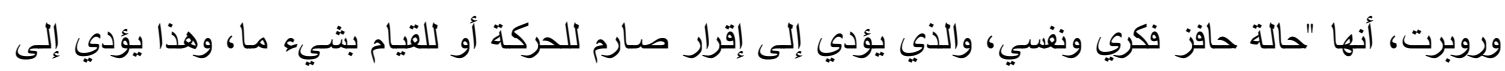

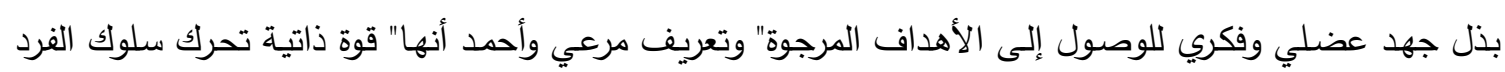

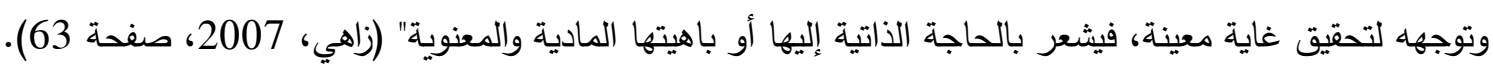

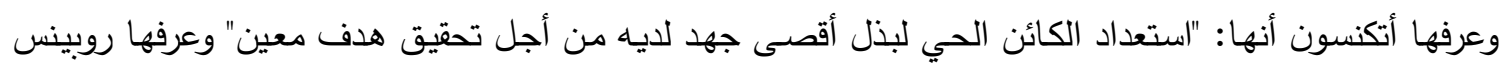

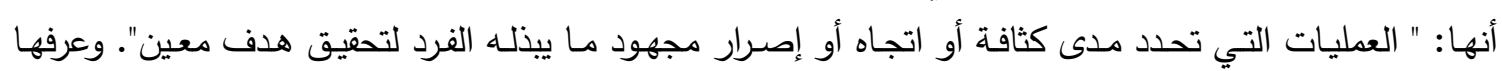


غراي: أنها المدى الذي يمكن أن يصل إليه الجهد المنطوي على إصرار ومثابرة عند توجهه نحو هدف معين". ويرى هامبتون أنها: "مجموعة القوى المنشطة والمحركة التي تأتي من داخل أو خارج الفرد بحيث تدفعسه لانتهاج سلوك معين". وعرفها ماسلو أنها: "خاصية ثابتة ومستمرة، ومتغيرة، ومركبة وعامـة تمارس تأثيراً في كل أحوال

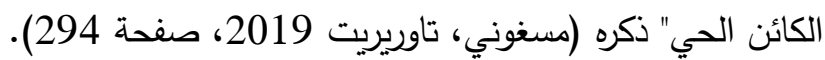

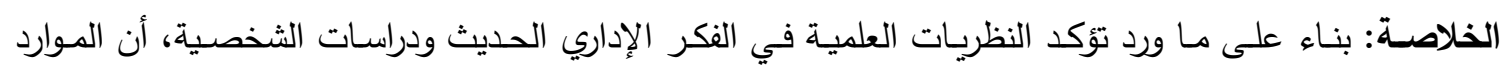

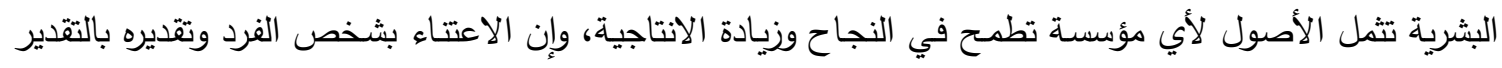
الملائم لرغباته واحتياجاته ورفع معنوياته في العمل؛ يعد المدخل الأول لاستمرارية تفوق المؤسسة وزيادة أرباحها. حيث اعتبرت النظريات الحديثة الإنسان كائن عاطفي يتأثر بالمشاعر والانفعالات والتي من شأنها أن تزيد الانتاجية

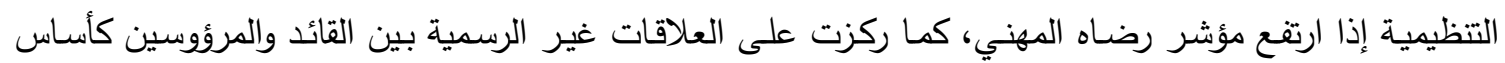

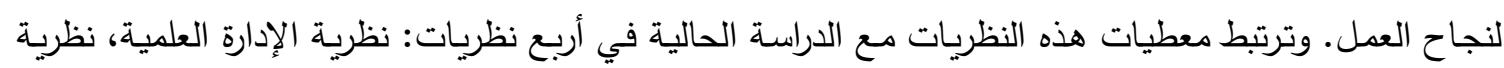

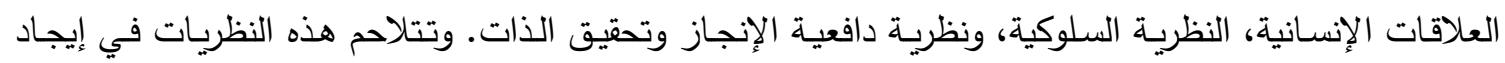
العوامل المؤثرة على التميز الوظيفي في القطاع الحكومي بدولة الإمارات العربية المتحدة. المنهجية والإجراءات

3.1 مجتمع الاراسة والعينة:

يثكل مجتمع الدراسة الموظفين الفائزين بجوائز التميز الوظيفي في وزارة التربية والتعليم بدولة الإمارات العربية المتحدة منذ العام 1995م الى العام 2020م وفق الجوائز المعتمدة في الدولة، والمحددة في الجدول: (3.1). وتكونت عينة الدراسة من (30\%) من مجتمع الدراسة حيث مثلت (283) من مجموع المجتمع الأصلي

(944) تم اختيارهم بالطريقة الطبقية العشوائية المتجانسة لضمان تمثيل عادل ومتساوي للعينة من جميع الجوائز .

جدول (3.1): مجتمع الدراسة يتكون من مجموع الفائزين في جوائز التميز الوظيفي

\begin{tabular}{|c|c|c|c|c|c|c|}
\hline الدراسة & 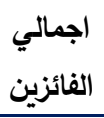 & الفئات المعنية & رقم الدورة في & التأسيس & اسم البرنامج/ الجايزة & p \\
\hline 96 & 321 & 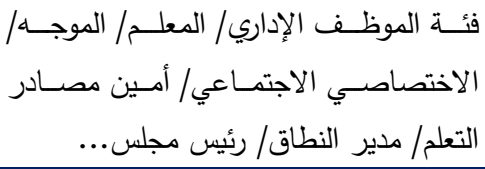 & 26 & 1995م & جائزة الثـارقة للتفـوق & 1 \\
\hline 119 & 395 & 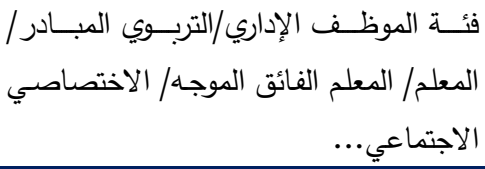 & 22 & 1998م & 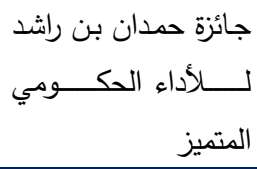 & 2 \\
\hline 68 & 228 & 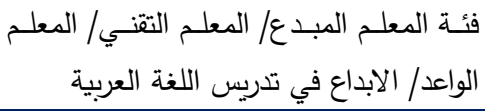 & 13 & 2007 & جائزة خليفة التربوية & 3 \\
\hline 283 & 944 & - & - & - & الاجمالي & \\
\hline
\end{tabular}

3.2 (أداة جمع البيانات:

لتحقيق أهداف الدراسـة قامت الباحث بتصميم أداة الدراسـة المتمثلة في (الاستبانة) بعد الاطـلاع على التح

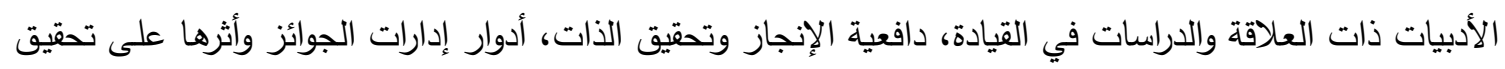

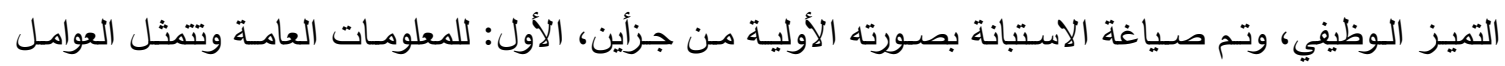


الديموغرافية (الجهة المانحة للجائزة/ الفئة الوظيفية/ المستوى التعليمي/ سنوات الخبرة/ الجنس). والثاني: يتضمن (5) مجالات رئيسية تعبر عن متغيرات الدراسة، تتفرع عنها (10) محاور و(55) عبارة كما يوضح في الجنول: (3.2)

جدول (3.2): هيكل توزيع المتغيرات الفرعية ومفردات العبارات مع توضيح المصدر

\begin{tabular}{|c|c|c|c|c|}
\hline مصدر العبارات & عدد العبارات & المحاور & نطاق المتغير & نوع المتغير \\
\hline 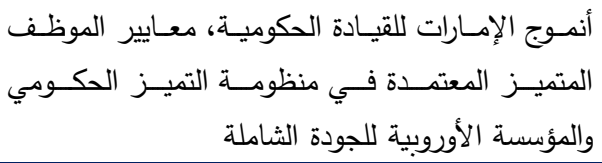 & 5 & - & التميز الوظيفي & المتغير التابع \\
\hline \multirow{3}{*}{ 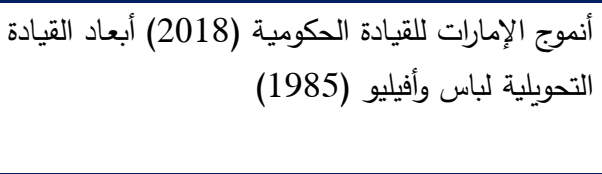 } & 5 & الروح القيادية & \multirow{3}{*}{ القيادة } & \multirow{3}{*}{ المتغير المستقل } \\
\hline & 5 & النظرة المستقبلية & & \\
\hline & 5 & الإنجاز والتأثير & & \\
\hline \multirow{3}{*}{ (1988) الحكومي (2009) والمؤسسة الأوروبية للجودة الثناملة } & 5 & الأداء والإنجاز & \multirow{3}{*}{ الموظف المتميز - ارسات } & \multirow{3}{*}{ المتغير المستقل } \\
\hline & 5 & المبادرة والابتكار & & \\
\hline & 5 & التعلم المستمر & & \\
\hline \multirow{2}{*}{ 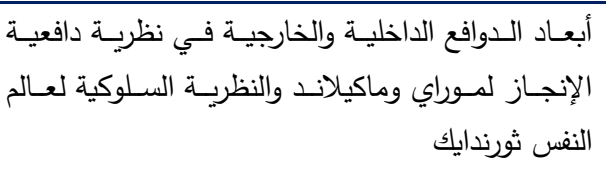 } & 5 & دوافع داخلية & \multirow{2}{*}{ وافعية الانجاز } & \multirow{2}{*}{ المتغير المؤثر } \\
\hline & 5 & دوافع خارجية & & \\
\hline \multirow{2}{*}{ عبارات من الخبرة المهنية للباحثة التي امتدت نحو فيز عجال } & 5 & أدوار إدارات & \multirow{2}{*}{ جوائز التميز } & \multirow{2}{*}{ خارجي - المتغير المؤثر } \\
\hline & 5 & ملائمة معايير & & \\
\hline
\end{tabular}

وصيغت جميع عبارات الاستبانة صياغة إيجابية، باختيار الدرجة (1) لاستجابة المبحوثين "غير موافق بشدة"، وأعطي لكل فقرة الوزن النسبي (20\%) مدرجاً على مقياس ليكرت (Likert) الخماسي لتقدير درجة أهمية العبارة

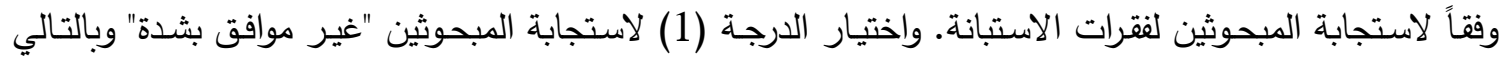
يكون الوزن النسبي هو (20\%) وهو يُعد مناسب مـع الاستجابة، واعتمـاداً على مـا تقدم فإن قيم المتوسطات

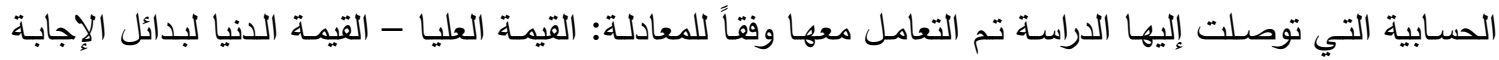
مقسومة على عدد المستويات، وهذه القيمة تساوي طول الفئة. وبذلك يكون المستوى المنخفض من (1.00 + 1.33

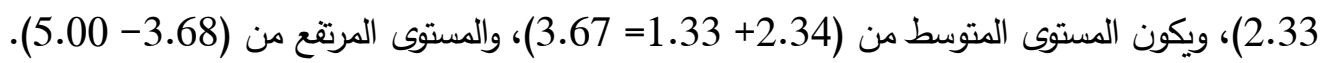

(الدراسة الاستطلاعية

قامت الباحثة في 2019م بطرح استطلاعات رأي حول أثر وأدوار القيادات تجاه تحفيز وتقدير جهود

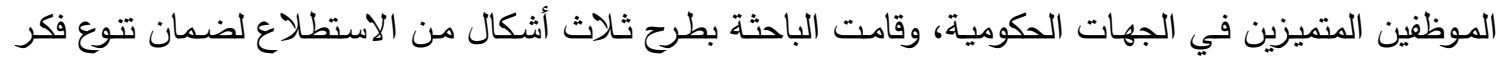
ومستويات المشاركين، وذلك على النحو الآتي: الأول: مقابلات شخصية مع المختصين في مجال التميز الوظيفي ومجال برامج تطوير القيادات الحكومية شملت

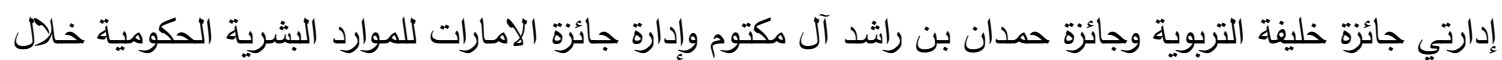
مايو، يونيو، ويوليو 2019م. (بحلوق: مقابلة شخصية: 2019؛ العفيفي، مقابلة شخصية: 2019) 
الثاني: صمدت الباحثة استطلاعاً بعدد من الأسئلة أطلقها عبر منصة "جوجل" الإككترونية لرصد انطباعات موظفي القطاع الحكومي من فئة الفائزين في الجوائز معتمداً على الأسئلة المفتوحة. شارك فيه فيه (38) موظفاً من الجهات الحكومية من فئة الحاصلين على جوائز التميز الوظيفي، وذلك خلال يوليو 2019، واستمر على مدى فئل (14) يوماً. للثالث: صمدت الباحثة استطلاع رأي إلكتروني لموظفي القطاع الحكومي بثكل عام، عبر تطبيق التيق (قصة) في قناة التواصـل الاجتمـاعي (insta@ excellence_mjs) وذلك في 10 يوليو 2019م. شـارك فيـه (53) شخصـاً بمستويات ثقافية عامة، وجاءت النتائج أن نسبة (60\%) يرون أن للقائد دور في دعم وتحفيز الموظفين للمشاركة

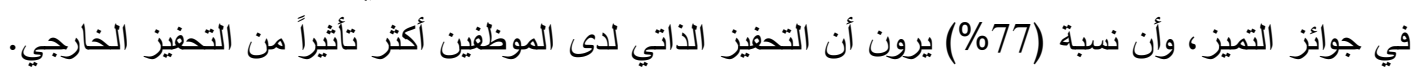

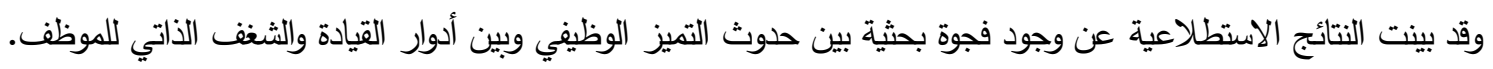

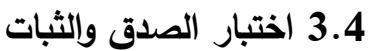

أ- - اختبار الصدق: صدق المحتوى (Content Validity): تم عرض أداة القياس على مجموعة من المحكمين

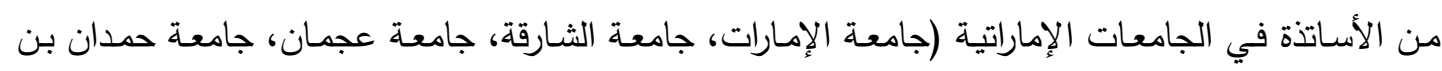

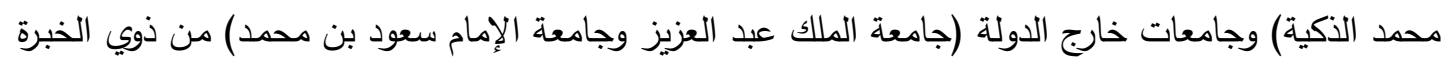

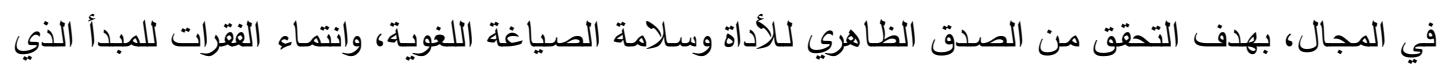

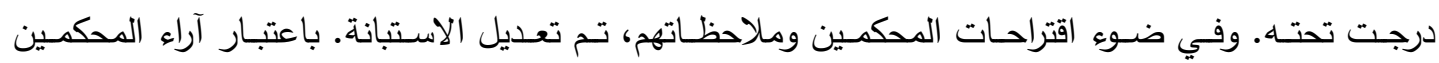
وتعديلاتهم دلالة على صدق محتوى الأداة وملاءمة فقراتها وتتوعها.

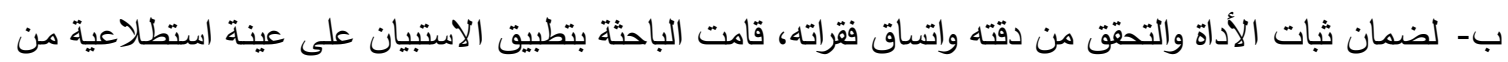

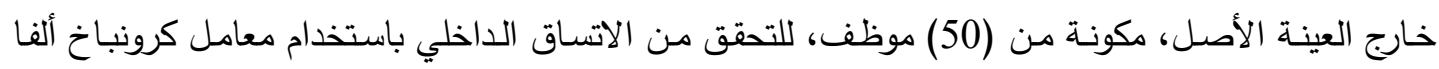

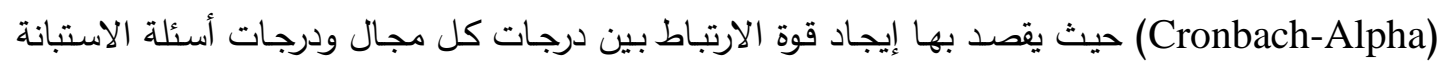

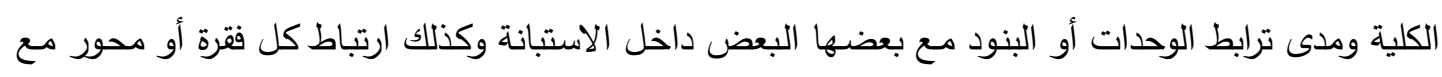

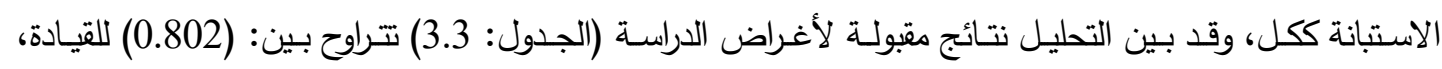

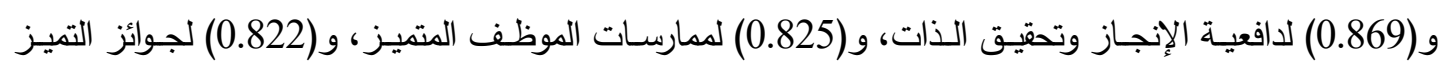

الوظيفي. حيث يفترض أن تتجاوز قيم معاملات ألفا كرونباخ عن (0.70) كما أشنار إليه (Hair et al., 2010).

جدول (3.3): هيكل توزيع المتغيرات الفرعية ومفردات العبارات مع توضيح المصدر

\begin{tabular}{|c|c|c|}
\hline معامل كرونباخ ألفا & عدد الفقرات & الأبعاد \\
\hline 0.802 & 15 & القيادة \\
\hline 0.869 & 10 & دوافع الإنجاز وتحقيق الذات \\
\hline 0.825 & 15 & ممارسات الموظف المتميز \\
\hline 0.822 & 10 & جوائز التميز الوظيفي \\
\hline
\end{tabular}

3.5

قامت الباحثة باستخدام مجموعة من الأساليب الإحصائية الوصفية والتحليلية وذلك من خلال استخدام

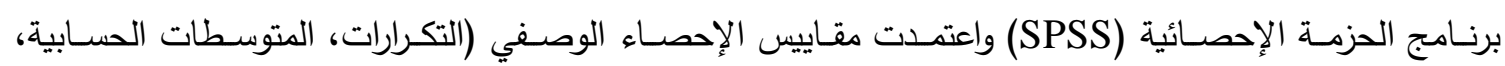

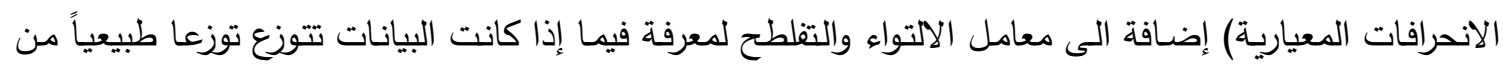

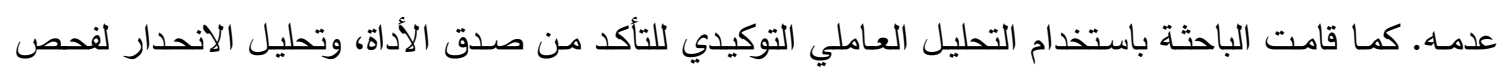

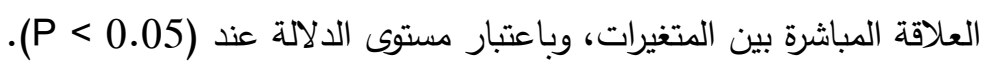


توصلت نتائج الدراسة من خلال الإجابة على أسئلة الدراسة عن أثر القيادات على الموظفين المتميزين في وزارة التربية والتعليم تعزي حصولهم على جوائز التميز الوظيفي وفق أبعاد أنموذج الإمارات للقيادة الحكومية: الروح القياديـة، النظرة المستقبلية، التأثير والإنجاز ، وأثر دوافع الإنجـاز وتحقيق الذات لدى المـوظفين المتميزين تعزي حصولهم على جوائز التميز الوظيفي وفق أبعاد الدوافع الداخلية والخارجية، وأثر ممارسـات الموظفين المتميزين تعزي حصوله على جوائز التميز الوظيفي وفق معايير التميز المعتمدة: الأداء والإنجاز ، المبادرة والابتكار، التعلم المستمر ، وأخيراً أثر بـرامج وجوائز التميز التربويـة على الموظفين المتميزين تعزي حصـولهم على جوائز التميز الوظيفي وفق أبعاد: أدوار إدارات الجوائز ، ملائمة معايير التميز • وقد أظهرت نتائج التحليل الاحصائي للبيانات بعد معالجتها وفق الأسئلة البحثية تأثيراً مرتفعاً في المتوسط العام بلغ (3.68)، ومتفاوت في الأبعاد التفصيلية، وذلك على النحو الآتي (الجدول: 4.1) و (الثكل: 4.1):

جدول (4.1): المتوسطات السحابية والانحرافات المعيارية لاستجابات المبحوثين في عينة الاراسة

\begin{tabular}{|c|c|c|c|c|c|c|c|}
\hline المدى الم & الترتيب & الانحراف المعياري & \multicolumn{2}{|c|}{ المتوسط الحسابي } & \multicolumn{2}{|c|}{ الأبعاد } & م \\
\hline \multirow{3}{*}{ متوسط } & \multirow{3}{*}{ الرابع } & \multirow{3}{*}{1.14} & \multirow{3}{*}{3.62} & 3.65 & الروح القيادية & \multirow{3}{*}{ القيادة } & \multirow{3}{*}{1} \\
\hline & & & & 3.58 & النظرة المستقبلية & & \\
\hline & & & & 3.63 & التأثير والإنجاز & & \\
\hline \multirow{2}{*}{ مرتفع } & \multirow{2}{*}{ ال الأول } & \multirow{2}{*}{1.07} & \multirow{2}{*}{3.72} & 3.75 & الدوافع الداخلية & \multirow{2}{*}{ وتحقيق الإذات } & \multirow{2}{*}{2} \\
\hline & & & & 3.69 & الدوافع الخارجية & & \\
\hline \multirow{3}{*}{ مرتفع } & \multirow{3}{*}{ الثاني } & \multirow{3}{*}{1.02} & \multirow{3}{*}{3.71} & 3.69 & الأداء والإنجاز & \multirow{3}{*}{ ممارسات الموظف } & \multirow{3}{*}{3} \\
\hline & & & & 3.73 & المبادرة والابتكار & & \\
\hline & & & & 3.71 & التعلم المستمر & & \\
\hline \multirow{2}{*}{ متوسط } & \multirow{2}{*}{ الثالث } & \multirow{2}{*}{1.12} & \multirow{2}{*}{3.66} & 3.68 & أدوار الإدارات & \multirow{2}{*}{ جوائز التميز } & \multirow{2}{*}{4} \\
\hline & & & & 3.64 & معايير التتافس & & \\
\hline مرتفع & - & - & \multicolumn{2}{|c|}{3.68} & \multicolumn{3}{|c|}{ المتوسط العام } \\
\hline
\end{tabular}

الثكل (4.1): المتوسطات السحابية والانحرافات المعيارية لاستجابات المبحوثين في عينة الدراسة

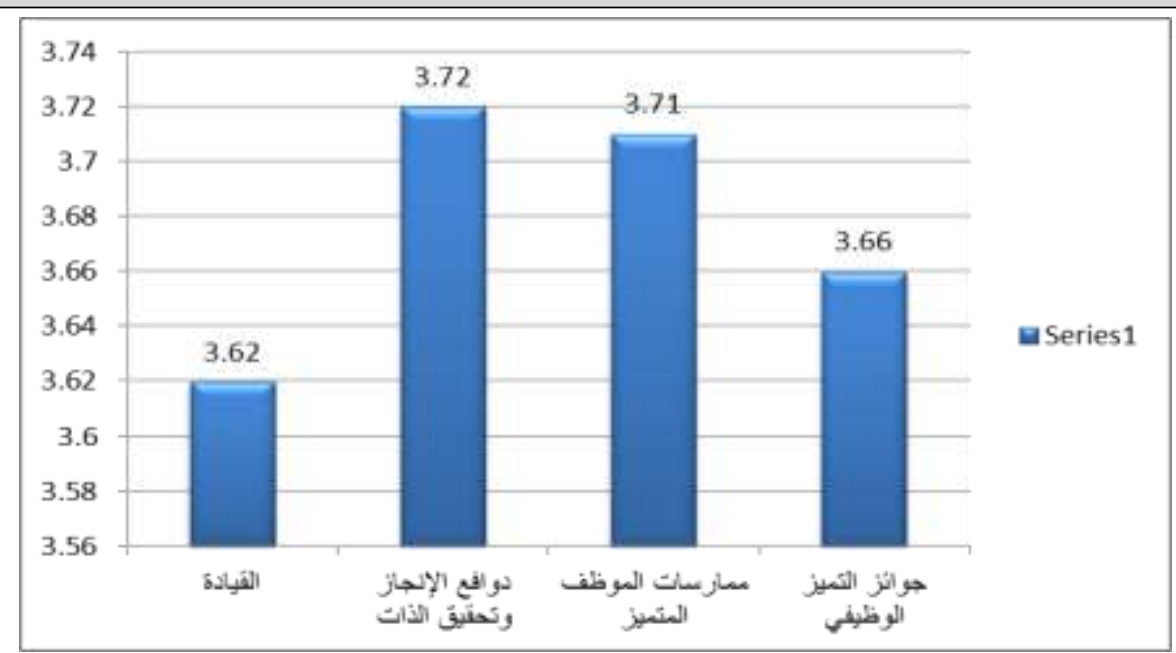


أولاً: تأثير القيادات على التميز الوظيفي وفق أبعاد أنموذج الإمارات للقيادة الحكومية: بينت نتائج الدراسة أن هناك

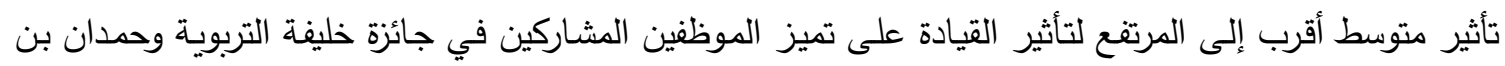

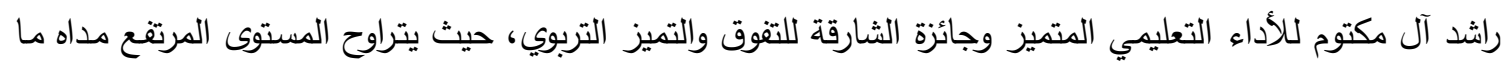

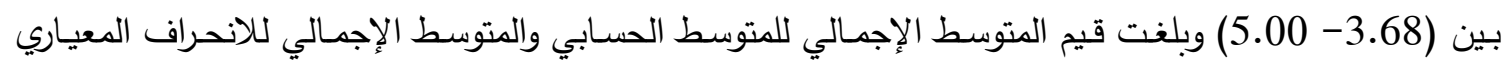
لأدوار القيادة على تعزيز التميز الوظيفي (3.62) و(1.14) على التوالي. وأظهرت النتائج التفصيلية لأبعاد القيادة:

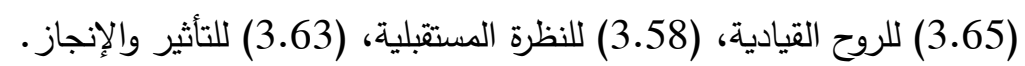
ثانياً: تأثير دوافع الإنجاز وتحقيق الذات وفق أبعاد الدوافع الداخلية والخارجية في نظريـة دافعية الإنجاز لموراي وماكيلاند والنظرية السلوكية لعالم النفس ثورندايك: بينت نتائج الدراسة أن هنالك تأثير مرتفع لدوافع الإنجاز وتحقيق الإنيق الذات لاى الموظفين المتميزين تسهم بشكل من الأشكال في حصولهم على جوائز التميز الوظيفي المتمثلة في جائزة

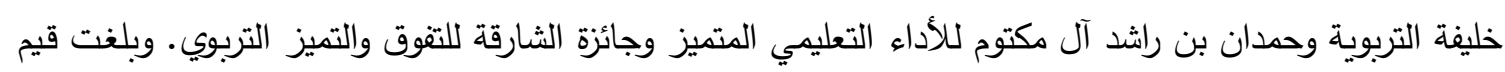

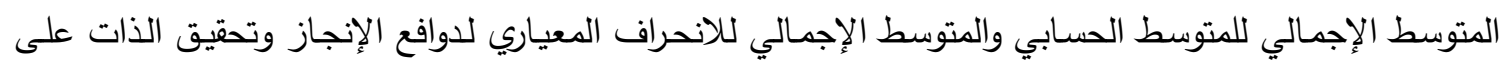
تعزيز التميز الوظيفي (3.72) و(1.07) على التوالي. وأظهرت النتائج التقصيلية لأبعاد الدوافع الداخلية (3.75) وبلغت لأبعاد الدوافع الخارجية (3.69). ثالياً: تأثير ممارسات الموظف المتميز وفق معايير الموظف المتميز المعتمدة في منظومة التميز الحكومي في دولة الإمارات ومعايير المؤسسة الأوروبية للجودة الثاملة: وقد أظهرت النتائج تأثير مرتفع لممارسات الموظف فئفيل المتميز تسهم في حصول الموظفين على جوائز التميز الوظيفي المتمثلة في جائزة خليفة التربوية وحمدان بن راشد آل مكتوم

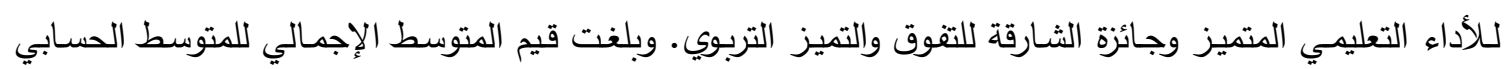
والمتوسط الإجمالي للانحراف المعياري لممارسات الموظف المتميز على تعزيز التميز الوظيفي (3.71) و و(1.02) على التوالي. وأظهرت النتائج التفصيلية لمعايير التميز الوظيفي: (3.69) لمعيار الأداء والإنجاز ، (3.73) لـعيار المبادرة والابتكار ، و(3.71) المعيار التعلم المستمر . رابعاً: تأثير برامج وجوائز التميز الوظيفي وفق أدوار إدارات التميز ومعاير التنافس في الجوائز : وقد أظهرت النتائج

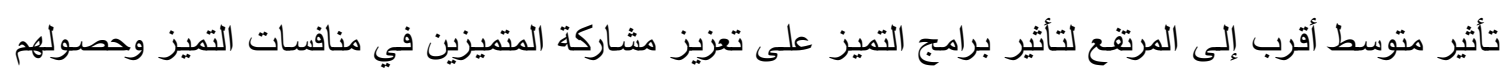

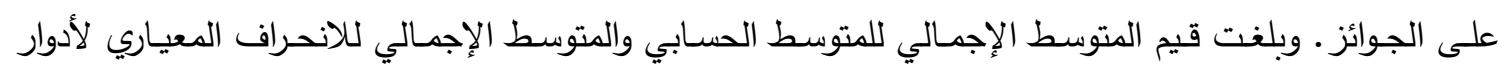
القيادة على تعزيز التميز الـوظيفي (3.66) و(1.12) على التوالي. وأظهـرت النتائج التفصيلية لأدوار إدارات الجوائز : (3.68) وتعبر عن قيمة مرتفعة، بينما بلغت (3.64) لمعايير التتافس وتعبر عن قيمة متوسطة.

الاستنتاجات والتوصيات

(الاستنتاجات

تهدف الدراسة قياس أثر أدوار القيادة ودافعية الإنجاز في تحقيق التميّز الوظيفي وأثر ممارسات الموظف

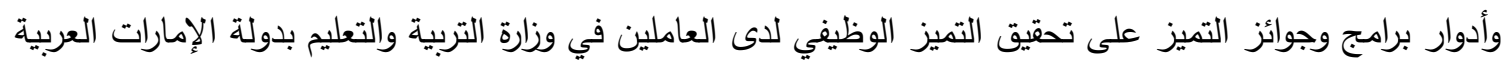

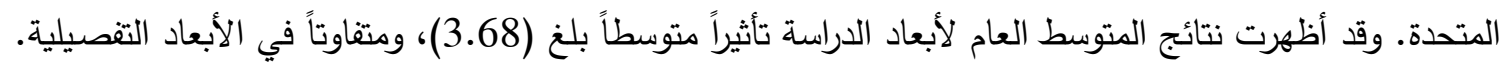

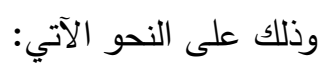

تثير نتائج البعد الأول (القيادة) إلى تأثير متوسط، واحتل بذلك الترتيب الرابع. بينما أظهرت في النتائج التفصيلية

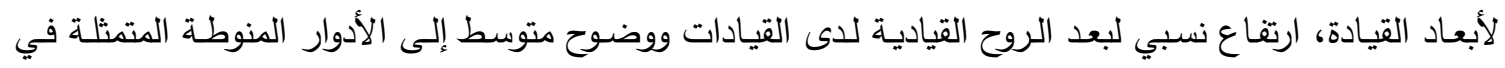

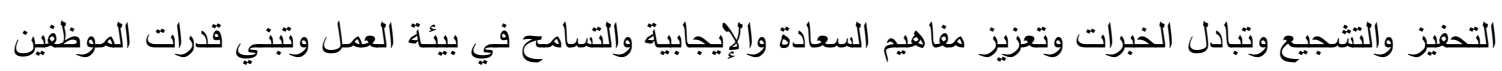


المتميزين. وأن هنـاك تعدد الأدوار القياديـة مـا بين النظرة المستقبلية ووضـع الخطط الاستراتيجية وتبني مفاهيم الابتكار والتجديد في بيئة العمل، من شأنه أن يضع التحفيز والتشجيع ضدن التهن الأولويات الثانوية للقائد.

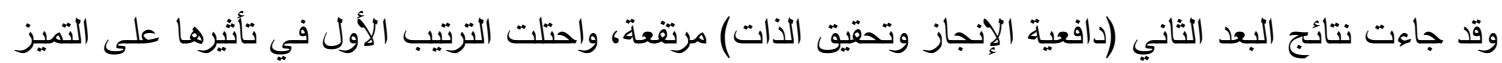

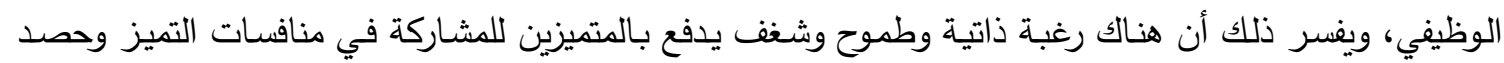

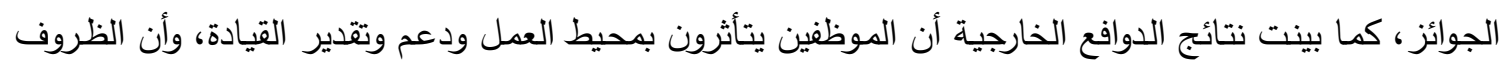
المحيطة من شأنها أن تؤثر على أدائهم سلباً أو إيجاباً، وترتبط هذه الجزئية بما ورد في نتائج أبعاد الروح القيادية.

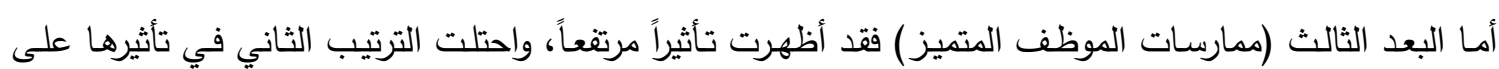
التميز الوظيفي، ويفسر ذلك أن هناك ثقة لدى الموظفين المتميزين في أدائهم وإنجازاتهم، ويتمتعون بروح المبادرة في تئي

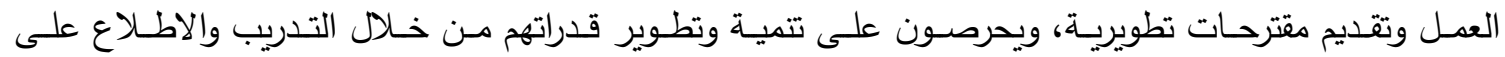

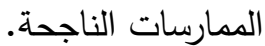
وتثير نتائج البعد الرابع (جوائز التميز الوظيفي) إلى تأثير متوسط، بينما أظهرت في النتائج التقصيلية للبعد الرابع تأثيراً مرتفعاً لأدوار إدارات الجوائز ومتوسطاً لملائمة معايير التتافس، ويفسر ذلك أن برامج التهير وجوائز التميز الوظيفي تلعب دوراً مرتفعاً مهماً في تثجيع المتميزين للمشاركة في منافساتها، وتعقد ورش تأهيلية وتدريبية حول فئاتها ومعاييرها، وتتمتع بقدر من المصداقية في نتائجها بناء على تحليل نتائج العينة، بينما تحتاج معايير التنافس إلى مئى المزيد من التوضيح والتفسير والواقعية والملائمة لظروف العمل الحكومي، وصياغة آليات واضحة لتوثيق الانجازات

وترى الباحثة أن نتائج الدراسـة بشكل عام تعكس الاستعداد الثخصسي للموظف المتميز ودوافعها الذاتيـة لتحقيق

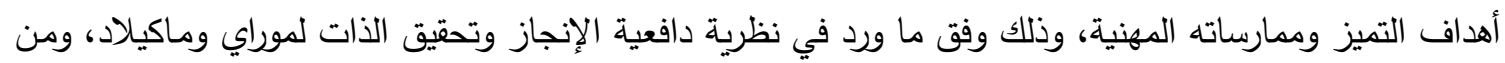

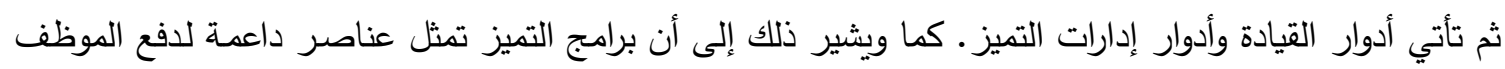

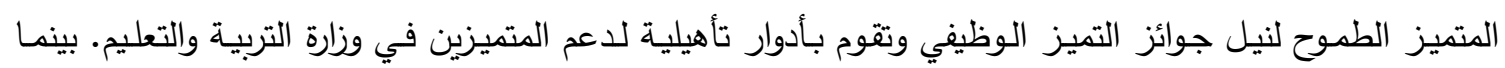

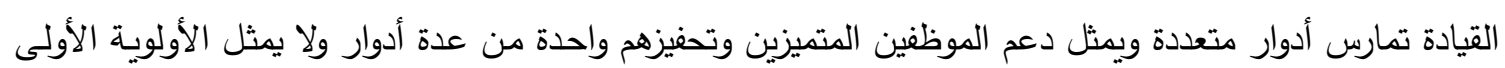

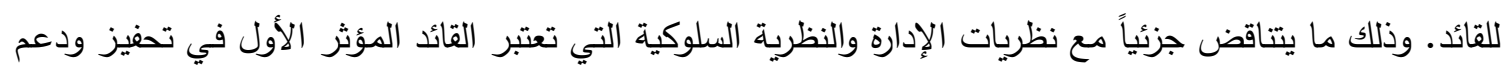
الموظفين. وتتوافق هذه النتائج مع بعض الدراسات السابقة، منها: دراسة السلوك القيادي للمشرفين في التعامل مع المعلمين،

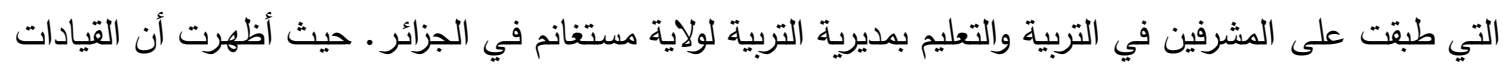
من المشرفين التربويين يتبعون أسلوب قيادي متوسط، وأن مستوى التفاوت بين المشرفين يعود للاجتهادات الثخصية

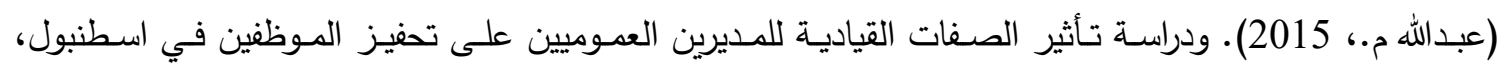

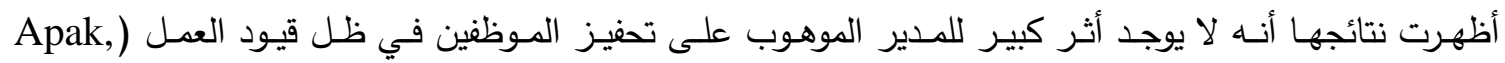

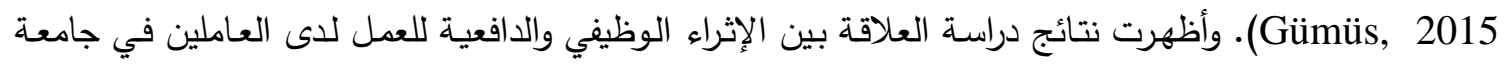
البلقاء التطبيقية أن درجة توافر عناصر الإثراء الوظيفي لاى الموظفين الإداريين ليست كبيرة وأن مستوى الدافعية

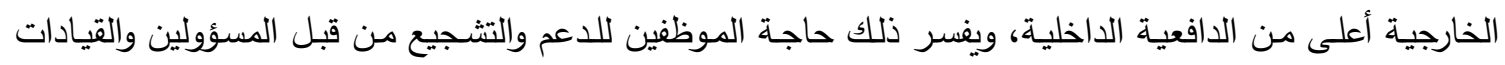

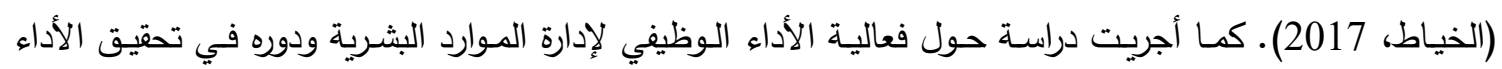

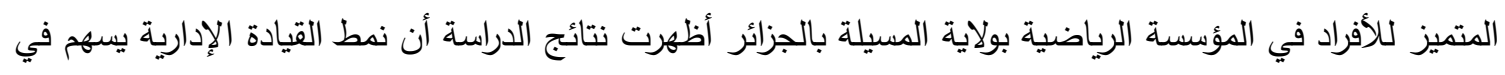

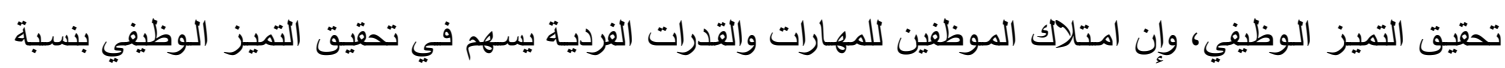
بلغت (73.30\%) (خربشي، 2019). بينما أظهرت دراسة درجة توافر سمات القيادة التحويلية لدى مديري المدارس فئس 
الثانوية بمحافظة غزة وعلاقتها بمستوى الانتماء المهني لمعلميهم، توافر السمات القيادية لمديري المدارس الثانويـة بدرجة كبيرة لكافـة أبعاد القيادة التحويلية بلـغ متوسطها (75.20\%) وعزت الباحثة النتيجة لحسن العلاقات بين المدراء والمعلمين والاهتمام بأفكار وتوجهاتهم، وحرص المدراء على تطوير وتتمية ذواتهج وتجنب الأساليب الروتينية

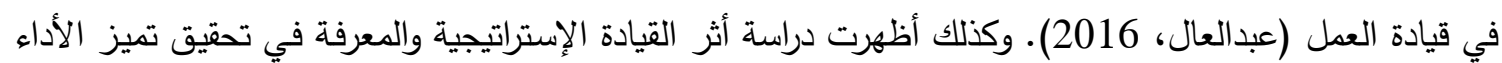
عن وجود أثر إيجابي للقيادة الإستراتيجية في تحقيق تميز الأداء، ووجود أثر إيجابي للقيادة التبادلية والقيادة التحويلية في زيادة المعرفة الضمنية لدى الموظفين دون المعرفة الظاهرة (عطاء، 2017). ودراسة النهط القيادي للمدراء وعلاقته بدافعية الإنجاز للى الطاقم الإداري، حيث كثفت النتائج عن وجود علاقة ارتباطية طردية بين السلوك القيادي ودافعية الإنجاز للى الطاقم الإداري، أي أنه كلما زاد نمط السلوك القيادي الديمقراطي كلما ارتفعت

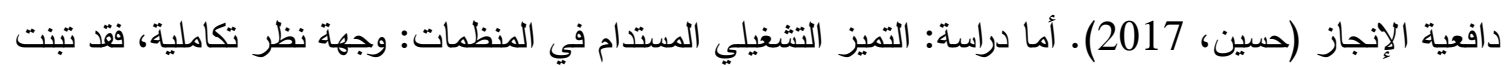

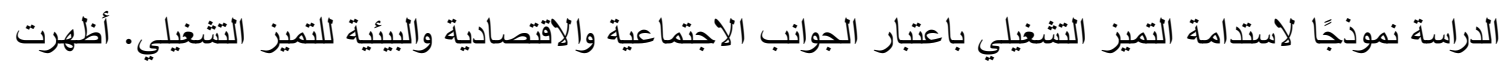
النتائج فاعلية برامج التميز الوظيفي في نجاح المبادرات قصيرة المدى، ولكنها لم تبين نجاحها على المدى البعيد، مما يستدل إلى غياب عنصر الاستدامة في التميز التثغيلي في المنظمة (Sony, 2019). 5.2 التوصيات: في ضوء نتائج الدراسة يوصى الباحث بما يلي: وزارة التربية والتعليم:

توصى الباحثة وزارة التزبية والتعليم بوضع سياسات التعزيز والتحفيز والتمكين ورعاية المتميزين في الأداء

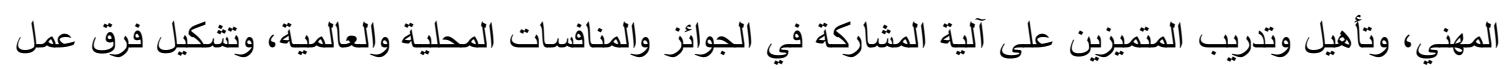

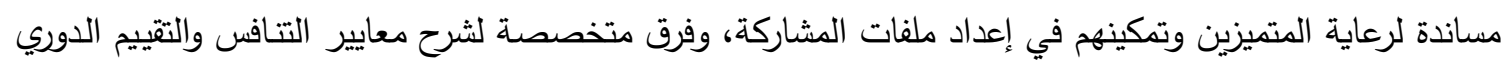

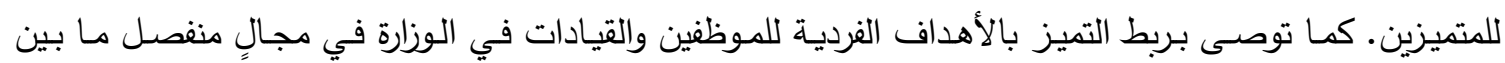

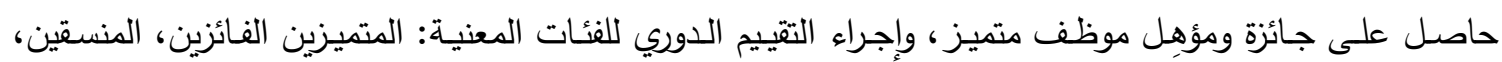
المتميزين من غير الفائزين، للوقوف على نقاط القوة وفرص التحسين في أداء فرق العمل على الجوائز . القيادات في الوزارة:

توصى الباحثة قيادات الوزارة بتطبيق سياسة التعزيز والتمكين لرعاية المتميزين في الأداء المهني، والعمل

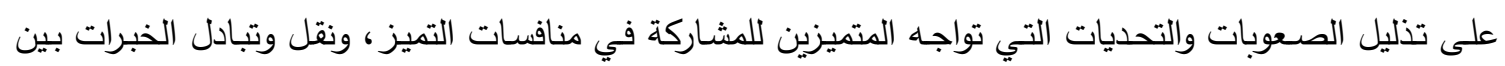
الفائزين في الإدارة، وتعميم التجارب الناجحة والمتميزة للفائزين على المستويات كافة. إدارات الجوائز:

توصسى الباحثة إدارات الجـوائز بتكثيف الـوش التأهيليـة في معـايير التميز ، ومراجعـة وتحديث دوري

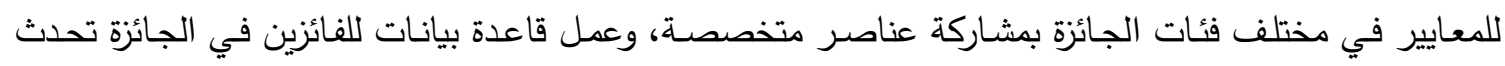

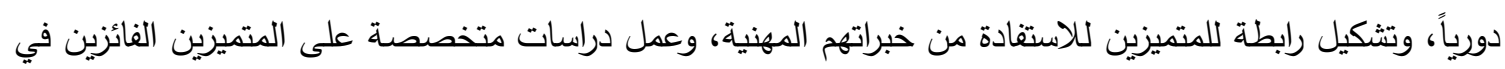

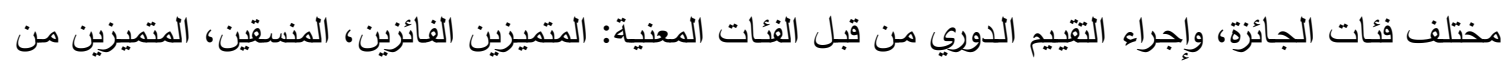
غير الفائزين للوقوف على نقاط القوة وفرص التحسين في أداء العام للجائزة المتميزين الفائزين في الجوائز:

توصى الباحثة المتميزين الحرص على نقل الخبرات والتبادل المعرفي مع زملاء العمل من داخل المؤسسة

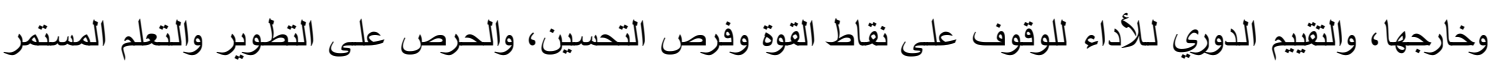
ومواكبة المستجدات ذات العلاقة بالوظيفة. ولعين. 
ابن منظور ، محمد المصري الأفريقي. (1986). لسان العرب - المجلد العاشر 2010. بيروت: دار صادر . إبراهيم مسغوني، ونور الدين تاويريت. (2019). الأنماط القيادية لمديري المدارس الابتدائية واثرها على الدافعية

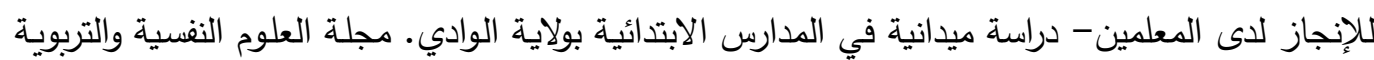

$$
\text { .285-288) } 2019 \text { (305) (3) }
$$

أحمد الثحي. (2019). إدارة المواد البشرية والأداء في القطاع الحكومي بين الحاضر والمستقبل. الإمارات: دبي: .JustCreative

أحمـ حسنين. (2019). القيـادة الأخلاقيـة وبنـاء قـادة الصـف الثاني بالمنظمـات العربيـة. الأردن: عمـان: دار

$$
\text { اليازوري العلمية للنشر والتوزيع. }
$$

إدوارد ج. موراي. (2017). الدافعية والإنفعال. (أحمد عبدالعزيز سلامة، المترجمون) دولة الكويت: مكتبة الفلاح

$$
\text { للنشر والتوزيع. }
$$

أمل العفيفي - جائزة خليفة التربوية، مقابلة شخصية: يوليو 2019

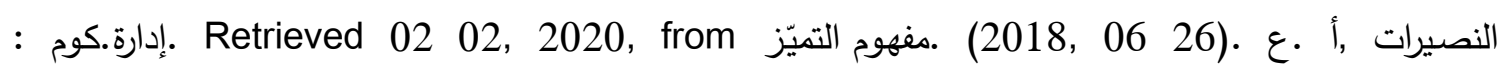
https://edara.com/Article/details/5235 بيتر ف. دراكر • (2011). أساسيات بيتر دراكر • بيروت: مكتبة لبنان ناشرون.

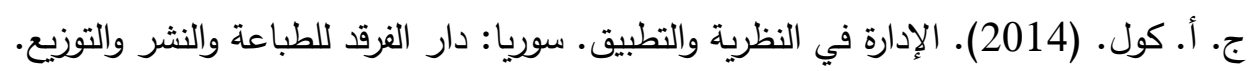

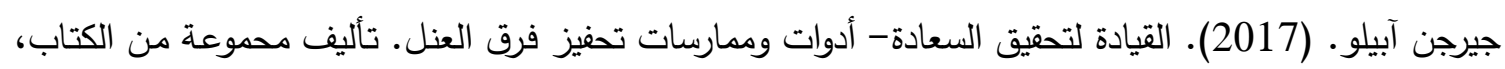

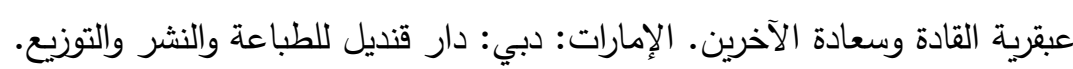

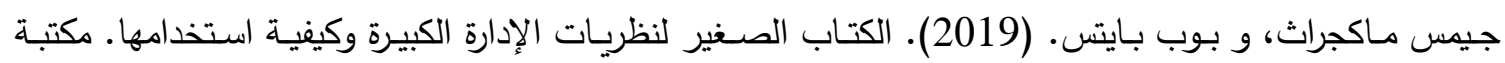
جرير

حسن بوزنـاق. (2020). التسيير الحديث للكفاءات في المؤسسة كمدخل لتحقيق الميزة التتافسية - دراسـة حالـة المجمع الصناعي بصيدال. أطروحة لنيل درجة الدكتوراة في علوم التسيير - تخصص الاقتصاد التطبيقي

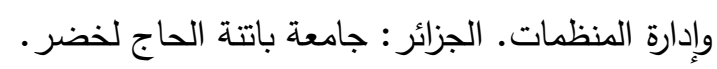

خالد بن محمد الرابغي. (2015). عادات العقل ودافعية الإنجاز . مركز ديبونو لتعليم التفكير.

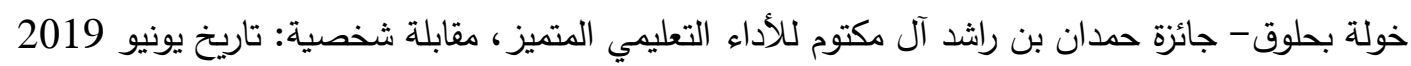
خولة عبدالعال. (2016). درجة توافر سمات القيادة التحويلية لدى مديري المدارس الثانوية بمحافظة غزة وعلاقتها

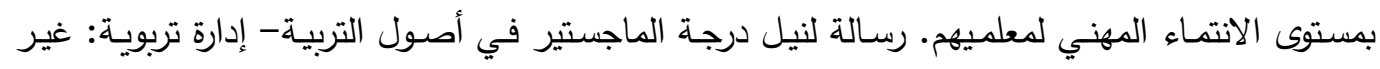

$$
\text { منشور • الجامعة الإسلامية: غزة. }
$$

دلال الجرايدة، و نهاية الجازية. (2015). دور جائزة الملكة رانيا العبدالله للمعلم المتميز في تحسين الأداء التعليمي

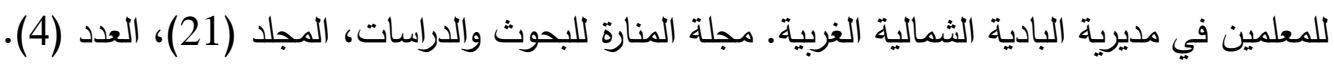

دي كامب. (2000). مدير القرن 21. المملكة العربية السعودية: الرياض: مكتبة الشقري. ديفيد بيندليتون، و فورنهام آدراين. (2019). كل ما ترغب معرفته عن القيادة. (عاصم سيد، المترجمون) القاهرة-

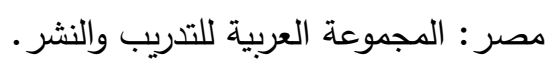

زينب بوهنة، و مريم بالهادي. (2014). إدارة الموارد البشرية في المؤسسـات الاقتصـادية. الجزائر : وزارة التعليم

$$
\text { العالي والبحث العلمي. }
$$


سيد الهواري. (1982). الإدارة الأصور والأسس العلمية. القاهرة: مكتبة عين شمس.

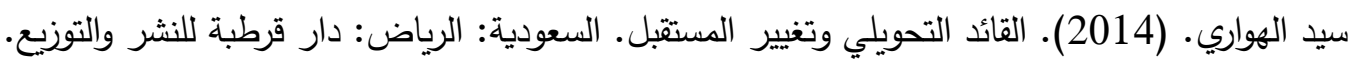

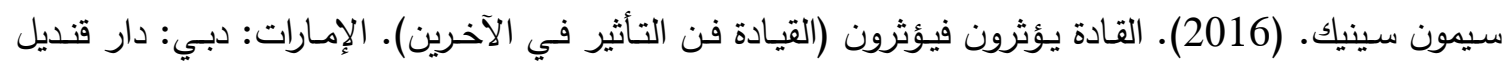
للطباعة والنشر والتوزبع.

شانتال بيرنز • (2018). التحفيز الفوري- الحقيقة المدهشة وراء مايحفز الأداء الأفضل. مكتبة جرير . شذى عطاء. (2017). أثر القيادة الإستراتيجية والمعرفة في تحقيق تميز الأداء بشركات الاتصـالات السودانية.

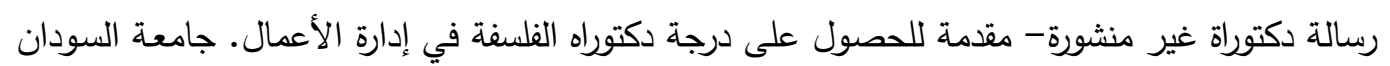

ل للعلوم والتكنولوجيا

صياحي الأخضـر • (2018). دور القيادة التحويلية في تحقيق التميز التنظيـي بالمؤسسـة الاقتصـادية. أطروحـة دكتوراه في علوم التيسيير • الجزائر : جامعة محمد بوضياف بادة بالمسيلة.

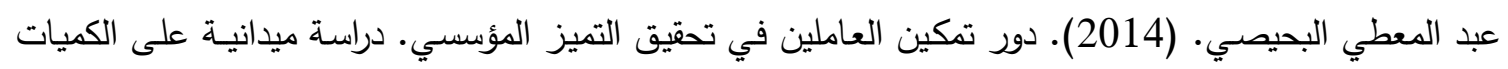
التقنية في محافظات قطاع غزة -رسالة ماجستير في إدارة الأعمال. فلسطين: جامعة التئ الأزهر . عبدالغفار حنفي. (2010). السلوك التنظيمي وإدارة الموارد البشرية. مصر : الإسكندرية: الدار الجامعية. عبدالغني أبوالعزم. (2013). معجم الغني الزاهر . القاهرة: دار الغني للنشر والتوزيع.

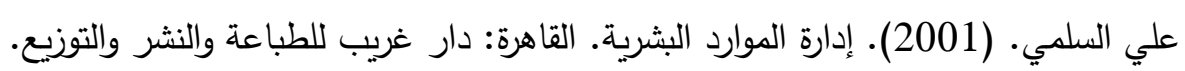
فيصل خربشي. (2019). فعالية الأداء الوظيفي لإدارة الموارد البشرية ودوره في تحقيق الأداء المتميز للأفراد في المؤسسة الرياضية. رسالة ماجستير غير منشورة. الجزائر: جامعة محمد بوضياف بالمسيلة. قابن حسين. (2017). النمط القيادي للمدراء وعلاقته بدافعية الانجاز لدى الطاقم الإداري في المركبات الرياضية

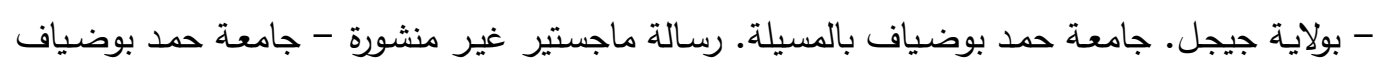

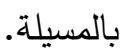

ماجد الخياط. (2017). العلاقة بين الإثراء الوظيفي والدافعية للعمل لدى العاملين في جامعة البلقاء التطبيقية: دراسة تطبيقية مسحية لموظفي مركز الجامعة. مجلة جامعة النجاح للإبحاث للعلوم الإنسانية: الأردن -

$$
\text { المجلد (31) العدد (08) } 2017 .
$$

محمد بن راشد آل آل مكتوم. (2018). قصتي. الإمارات العربية المتحدة- دبي: إكسبلورر للنشر والتوزيع.

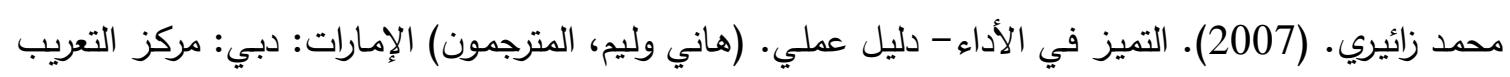
والنشر : الكلية الإكترونية للجودة الثاملة.

محمد قاسم القريوتي. (2013). مقدمة في الإدارة العامة. الكويت: مكتبة الفلاح للنشر والتوزيع.

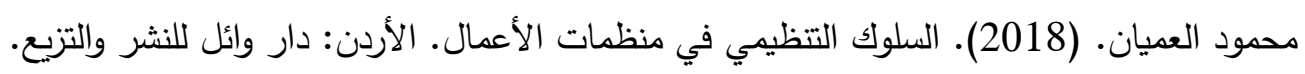

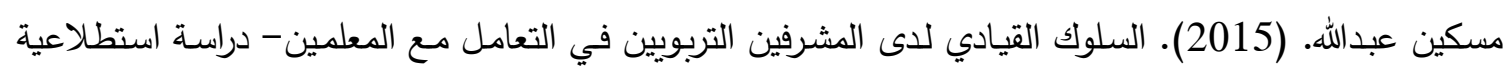

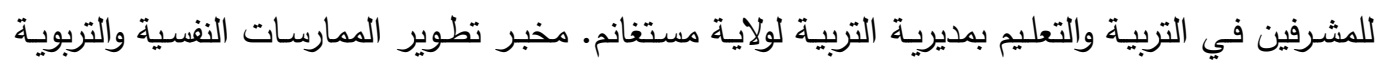

$$
\text { العدد (15). جامعة وهران: الجزائر. }
$$

مصطفى يوسف كافي. (2018). إدارة المواهب البشرية في المنظمات. الجزائر : ألفا للوثائق نشر واستيراد وتوزيع الكتب.

منال البارودي. (2016). القائد المتميز وأسرار الإبداع القيادي. القاهرة: المجموعة العربية للتدريب والنشر . 
منصور بن زاهي. (2007). الثعور بالاغتراب الوظيفي وعلاقته بدافعية الإنجاز للى الإطارات الوسطى لقطاع

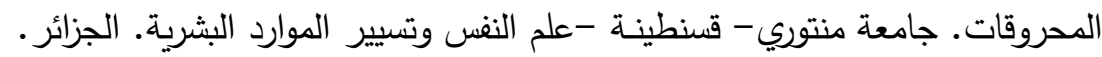
منى جواد سلمان. (2018). الحوكمة في ضوء نماذج التميّز المؤسسي. الثارقة: مكتبة الجامعة .

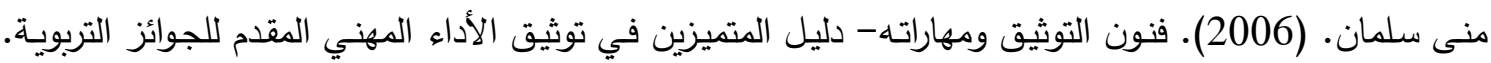
الإمارات: مكتبة دبي للتوزيع.

ياسر كداو. (2016). إدارة الموارد البشرية بين النظرية والتطبيق. دبي: دار الكتب. يحي جاسر أبوجودة. (2019). الذكاء الاجتماعي ودافعية الإنجاز • (عمان- الجامعة الأردنية، المحرر) المملكة الأردنية الهاشمية: دار زهدي للنشر والتوزيع.

مواقع الانترنت

قاموس المعاني، نت Retrieved 12 26, 2019, from . (2010) .الدافعية : https://www.almaany.com/ar/dict/arar/\%D8\%A7\%D9\%84\%D8\%AF\%D8\%A7\%D9\%1\% D8\%B9\%D9\%8A\%D8\%A9/

استراتيجية الهيئة الاتحادية للموارد البشرية الحكومية , Retrieved 06 13, 2020, (2016) .2012) from https://www.fahr.gov.ae مجلة صدى الموارد البشرية. (01 11, 2017). تاريخ الاسترداد 13 06, 2020، من الهيـة الإتحاديـة للموارد البشرية الحكومية- مجلة شهرية العدد (7): www.fahr.gov.ae

مجلة صدى الموارد البشرية. (2018). تاريخ الاسترداد 08 03, 2020، من الهيئة الاتحاديـة للموارد البشرية الحكومية - مجلة شهرية العدد (91): www.fahr.gov.ae

https://www.iyfnet.org/search/site :مؤسسة الثباب الدولية. تاريخ الاسترداد 02 07, 2020 الهيئة الاتحادية للموارد البشرية الحكومية. (17 10, 2019). تاريخ الاسترداد 02 02, 2020، دن عن الهيئة: https://www.fahr.gov.ae/Portal/ar/about-fahr/about-fahr.aspx برنامج الثيخ خليفة للتميز الحكومي Retrieved 10 01, 2019, from . (2019). منظومة التميز الحكومي : https://www.skgep.gov.ae/

قاموس المعاني Retrieved 5 5, 2019, from . (2019) .تعريف ومعنى الإدارة في معجم المعاني الجامع : https://www.almaany.com/ar/dict/ar$\operatorname{ar} / \% D 8 \% A 7 \% D 9 \% 84 \% D 8 \% A 5 \% D 8 \% A F \% D 8 \% A 7 \% D 8 \% B 1 \% D 8 \% A 9 /$

منظومة التميز الحكومي Retrieved 10 01, 2019, from . (2019) .برنامج الثيخ خليفة للتميز الحكومي : https://www.skgep.gov.ae/

وزارة شؤون مجلس الوزراء والمستقبل Retrieved 01 13, 2019, from . مبرنامج قيادات حكومة : https://www.mocaf.gov.ae الإمارات 


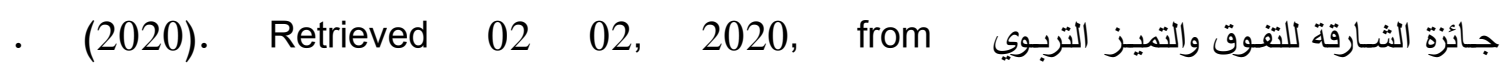
https://sharjahaward.shj.ae

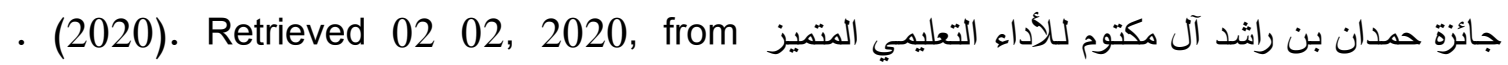
http://ha.ae

جائزة خليفة التربوية.Retrieved 02 02, 2020, from https://khaward.ae (2020). Ret

\section{References:}

Abdul Ghaffar Hanafi (2010). Organizational behavior and human resource management. Egypt: Alexandria: University House. (in Arabic)

Abdul Muti Al-Buhaisi (2014). The role of empowering workers in achieving institutional excellence. Field study on technical quantities in the governorates of the Gaza Strip - Master of Business Administration thesis. Palestine: Al-Azhar University. (in Arabic)

Abdul-Ghani Abu Al-Azm. (2013). The Dictionary of the Rich Al Zahir. Cairo: Dar AlGhani for Publishing and Distribution. (in Arabic)

Ahmed Al Shehhi (2019). Managing human resources and performance in the government sector between the present and the future. UAE: Dubai: JustCreative. (in Arabic)

Ahmed Hassanein (2019). Ethical leadership and building second-grade leaders in Arab organizations. Jordan: Amman: Al-Yazouri Scientific House for Publication and Distribution.(in Arabic)

Al Ghufli, A. A. (2012). Implementation of Business Excellence Model: A Case Study of UAE Public Sector Organisation. The University of Manchester (United Kingdom).

Ali Al-Salami (2001). Human Resource Management. Cairo: Dar Gharib for Printing, Publishing and Distribution. (in Arabic)

Alqaydi, E. S. (2015). Investigating the Factors of the Police Force Culture That Influence the Maintenance of the EFQM Excellence Model within the United Arab Emirates. Al-Fikr Al-Shurti, 78(1867), 1-117.

Amal Al-Afifi- Khalifa Award for Education, personal interview: July 2019.(in Arabic) Apak, S., \& Gümüş, S. (2015). A research about the effect of the leadership qualities of public administrators on the motivation of the employees. Procedia-Social and Behavioral Sciences, 210, 368-377. https://doi.org/10.1016/j.sbspro.2015.11.384

Basit, A., Sebastian, V., \& Hassan, Z. (2017). Impact of leadership style on employee performance (A Case study on a private organization in Malaysia). International Journal of Accounting \& Business Management, 5(2), 112-130.

Chantal Burns (2018). Instant Motivation - The surprising truth behind what drives better performance. Jarir Library. (in Arabic)

Chaza Attaa (2017). The impact of strategic leadership and knowledge in achieving performance excellence in Sudanese telecom companies. Unpublished $\mathrm{PhD}$ Thesis - Introduction to the Ph.D. degree in Business administration. The University of Sciences and technology: Sudan. (in Arabic)

D. Camp (2000). The Leader of the 21st Century. Kingdom of Saudi Arabia: Riyadh: AlShakari Library. (in Arabic) 
Dalal Al-Jarida and Nihaya Al-Jaziya (2015). The role of the Queen Rania Al Abdullah's Award for Distinguished Teacher in improving the educational performance of teachers in the northwestern Badia district. Al-Manara Journal for Research and Studies, 21(4). (in Arabic)

David Pendleton and Fornham Adrien (2019). All you need to know about driving. (Assem Sayed, the translators) Cairo - Egypt: The Arab Group for Training and Publishing. (in Arabic)

Edward J. Murray (2017). Motivation and emotion. (Ahmed Abdulaziz Salama, translators) State of Kuwait: Al-Falah Library for Publishing and Distribution. (in Arabic)

Faisal Kharbashi (2019). The effectiveness of the job performance of human resources management and its role in achieving the distinguished performance of individuals in the sports organization. Unpublished master thesis. Algeria: University of Mohamed Boudiaf of Masila. (in Arabic)

Graves, L. M., \& Sarkis, J. (2018). The role of employees' leadership perceptions, values, and motivation in employees' provenvironmental behaviors. Journal of Cleaner Production, 196, 576-587. https://doi.org/10.1016/j.jclepro.2018.06.013

Hamad Qasim Al-Qaryouti (2013). Introduction to Public Administration. Kuwait: $A l$ Falah Library for Publishing and Distribution. (in Arabic)

Hassan Bouznak (2020). Modern management of competencies in the organization as an entry point to achieve competitive advantage - A case study of the industrial complex in Sidon. Thesis for a PhD in Management Sciences - Specialization in Applied Economics and Organization Management. Algeria: University of Batna El Hadj Lakhdar. (in Arabic)

Ibn Manzour, Muhammad Al-Masry Al-Africi (1986). Lisan Al Arab - Volume 10. 2010. Beirut: Dar Sader.(in Arabic)

Ibrahim Massghony, Noureddin Tauryt (2019). The leadership styles of primary school principals and their effect on the motivation of teachers' achievement - a field study in primary schools in the state of the valley. Journal of Psychological and Educational Sciences, 3(5), 288-305. (in Arabic)

J.A. Cole (2014). Management in theory and practice. Syria: Dar Al Farqad for printing, publishing and distribution. (in Arabic)

James McGrath and Bob Bates (2019). The Little Book of Big Management Theories and and their use. Jarir Library. (in Arabic)

Jorj and Abelo (2017). Happiness Leadership - Tools and practices of employee motivation. Author of a group of writers, the genius of leaders and the happiness of others. Emirates: Dubai: Kandil House for Printing, Publishing and Distribution. (in Arabic)

Kanat-Maymon, Y., Elimelech, M., \& Roth, G. (2020). Work motivations as antecedents and outcomes of leadership: Integrating self-determination theory and the full range leadership theory. European Management Journal, 38(4), 555-564. https://doi.org/10.1016/j.emj.2020.01.003

Kassem, R., Ajmal, M. M., \& Khan, M. (2017). The relationship between organizational culture and business excellence: Case study from United Arab Emirates. In Organizational Culture and Behavior: Concepts, Methodologies, Tools, and Applications (732-751). IGI Global. https://doi.org/10.4018/978-1-5225-19133.ch035

Khalid bin Mohammed Al-Rabghi (2015). Habits of mind and achievement motivation. Debono Center for Thought Teaching Methods. (in Arabic) 
Khawla Abdel-Aal (2016). The degree of availability of transformational leadership traits among secondary school principals in Gaza governorate and their relationship to the professional affiliation level of their teachers. Thesis for a master's degree in the Foundations of Education - Educational Administration: Unpublished. Islamic University of Gaza. (in Arabic)

Khawla Bahloq. Hamdan Bin Rashid Al Maktoum Award for Distinguished Academic Performance, Personal Interview: June 2019. (in Arabic)

Mahmoud Al-Amian (2018). Organizational behavior in business organizations. Jordan: Wael Publishing and Distribution House. (in Arabic)

Majid Al-Khayyat (2017). The relationship between job enrichment and work motivation for employees at Al-Balqa Applied University: An applied survey study of university center employees. An-Najah University Research Journal for the Humanities: Jordan - 31(8). (in Arabic)

Manal Al-Baroudi (2016). The distinguished leader and the secrets of leadership creativity. Cairo: Arab Group for Training and Publishing. (in Arabic)

Mansour bin Zahi (2007). The feeling of job alienation and its relationship to achievement motivation among the middle tires of the hydrocarbon sector. Mentouri University - Constantine - Psychology and Human Resources Management. Algeria. (in Arabic)

Maxwell, J. C. (2019). Developing the Leader within You 2.0. jarir bookstore.

Meskin Abdullah (2015). Leadership behavior of educational supervisors in dealing with teachers - an exploratory study of supervisors in education in the Directorate of Education in Mostaganem State. Laboratory of developing psychological and educational practices, issue (15). University of Wahran: Algeria. (in Arabic)

Mohamed Zairi (2007). Excellence in Performance - A Practical Guide. (Hani William, the translators) UAE: Dubai: Arabization and Publishing Center: The Electronic College of Total Quality. (in Arabic)

Mohammed bin Rashid Al Maktoum (2018). my story. United Arab Emirates - Dubai: Explorer Publishing and Distribution. (in Arabic)

Mona Jawad Salman (2018). Governance in light of models of institutional excellence. Sharjah: University Library. (in Arabic)

Mona Salman (2006). Documentation Arts and Its Skills - A guide for the distinguished in documenting professional performance presented for educational awards. Emirates: Dubai Library for Distribution. (in Arabic)

Mustafa Youssef Kafi (2018). Managing human talent in organizations. Algeria: Alpha Documentation Publishing, Import and Distribution of Books. (in Arabic)

Peter F. Drucker (2011). Basics of Peter Drucker. Beirut: Lebanon Library Publishers. (in Arabic)

Qaben Hussein (2017). The leadership style of managers and its relationship to the achievement motivation of the administrative staff in sports vehicles - Jijel state. Hamad Boudiaf University in M'sila. Unpublished master's thesis - Hamad Boudiaf University, M'sila. (in Arabic)

Sayahi El-Akhdar (2018). The role of transformational leadership in achieving organizational excellence in the economic institution. $\mathrm{PhD}$ thesis in Management Sciences. Algeria: University of Mohamed Boudiaf of Masila. (in Arabic)

Shafi, M., Lei, Z., Song, X., \& Sarker, M. N. I. (2020). The effects of transformational leadership on employee creativity: Moderating role of intrinsic motivation. Asia Pacific Management Review, 25, (3), 166-176. https://doi.org/10.1016/j.apmrv.2019.12.002 
Simon Scenic (2016). Leaders influence (leadership is the art of influencing others). Emirates: Dubai: Kandil House for Printing, Publishing and Distribution. (in Arabic)

Sony, M. and Naik, S. (2019). Six Sigma with C-K theory for innovations in operational excellence: a case study, Benchmarking: An International Journal, 26 (7), pp.

2105-2121. https://doi.org/10.1108/BIJ-08-2018-0241

Syed Al-Hawari (1982). Graphic management and scientific foundations. Cairo: Ain Shams Library. (in Arabic)

Syed Al-Hawari (2014). Transformational Leader and Future Changing. Saudi Arabia: Riyadh: Cordoba House for Publishing and Distribution. (in Arabic)

Yasser Kadaw (2016). Human resource management between theory and practice. Dubai: House of Books. (in Arabic)

Yoshio Kondo (2005). Human motivation is an essential factor in management. Emirates: Dubai: Center for Arabization and Publishing at the Electronic College of Total Quality. (in Arabic)

Zainab Bouhna, and Maryam Bel Hadi (2014). Managing human resources in economic institutions. Algeria: Ministry of Higher Education and Scientific Research. (in Arabic) 